Portland State University

PDXScholar

$1-1-2010$

\title{
A Rabbi in the Progressive Era: Rabbi Stephen S. Wise, Ph.D. and the Rise of Social Jewish Progressivism in Portland, Or, 1900-1906
}

Mordechai Ben Massart

Portland State University

Follow this and additional works at: https://pdxscholar.library.pdx.edu/open_access_etds Let us know how access to this document benefits you.

\section{Recommended Citation}

Massart, Mordechai Ben, "A Rabbi in the Progressive Era: Rabbi Stephen S. Wise, Ph.D. and the Rise of Social Jewish Progressivism in Portland, Or, 1900-1906" (2010). Dissertations and Theses. Paper 729. https://doi.org/10.15760/etd.729

This Thesis is brought to you for free and open access. It has been accepted for inclusion in Dissertations and Theses by an authorized administrator of PDXScholar. Please contact us if we can make this document more accessible: pdxscholar@pdx.edu. 


\title{
A Rabbi in the Progressive Era: \\ Rabbi Stephen S. Wise, Ph.D. and the Rise of Social Jewish Progressivism in Portland, Or, 1900-1906
}

\section{A thesis in partial fulfillment of the requirements for the degree of}

\author{
Master of Arts \\ in \\ History
}

Thesis Committee:

David A. Horowitz Ken Ruoff

Friedrich Schuler

Michael Weingrad

\author{
Portland State University \\ 2010
}


ABSTRACT

Rabbi Stephen S. Wise presents an excellent subject for the study of Jewish social progressivism in Portland in the early years of the twentieth-century. While Wise demonstrated a commitment to social justice before, during, and after his Portland years, it is during his ministry at congregation Beth Israel that he developed a full-fledged social program that was unique and remarkable by reaching out not only within his congregation but more importantly, by engaging the Christian community of Portland in interfaith activities. In so doing, Wise broke off from the traditional role expected of rabbis by bringing social causes to the fore over traditional Jewish observances. This thesis examines the years and contributions of Stephen Wise in Portland between 1900 and 1906. An overall study of the Jewish community in Portland is presented along with a general description of the condition of how both German and Eastern European Jews through their settlement, business occupation, and pace of assimilation came to envision their integration into the American mainstream. In order to fully appreciate Wise's commitment to social progressivism in Portland, this study will look 
to detail how Liberal Judaism, Ethical Culture, and the Social Gospel movement provided Wise with the means to combine his rabbinate with public advocacy in the prophetic tradition. The thesis then focuses on Wise's social activities and struggles against child labor, gambling, and prostitution with a special interest on the Chinese Exclusion Acts that struck the small but active Chinese community of Portland. 


\section{ACKNOWLEDGEMENTS}

A master thesis, while - to a certain extent - a solitary undertaking, is difficult to endure and impossible to complete without the help and support of many. Thanks are due to my advisor, Prof. David A. Horowitz. He has since repeatedly proven his open-mindedness to my idiosyncrasies, and to the unusual type of student that is attracted to American Cultural history. Through the graduate program and his lectures, I have enhanced my understanding of popular culture along with the main historical events that have shaped America since its inception. He redeemed my work from numerous technical and conceptual errors and weighed in at various stages over the course of the writing with trenchant criticism and advice.

My gratitude also goes out to my thesis readers. First, Prof. Ken Ruoff, who herein, and having him agree to be on my committee proved to be not only an honor, but also a pleasure. During a year long of graduate studies in Modern Japanese history, his answers to my questions were always extremely thoughtful, elaborate and informed. A special thanks to Prof. Friedrich Schuler, who accepted at the last minute, to be part of this thesis committee. 
Lastly, Prof. Michael Weingrad, who for more than five years has been a great source of inspiration not only through his mentorship during my undergraduate years to advise me in my reading choices but also on the personal level. 
TABLE OF CONTENTS

ACKNOWLEDGEMENTS iii

INTRODUCTION

CHAPTER 1211

The Setting: Early Jewish Immigration

to Portland

CHAPTER 2

The Making of A Spiritual Leader

CHAPTER 3

The Struggle for Social Justice

CONCLUSION

BIBLIOGRAPHY 
INTRODUCTION

From 1897 up to his death in April 1949, the story of Rabbi Stephen S. Wise, Ph.D. (1874-1949) has regularly stirred historical and political uproar alike. Rabbi, scholar, preacher, social reformer, and political activist, Wise was a compelling public figure. In the course of his life, he wrote, preached, gave speeches on social and political matters, and established himself as the first recognized liberal Jew in America. Moreover, Wise's extraordinary oratory skills which won him a description by peers as "one of the best orators and cleverest debaters at the time,"1 promoted him as one of the most prominent and influential Jews to be active in social and justice progress in the United States during the first half of the twentieth century.

When Wise is recalled today, it is usually because of his fervent defense of the Zionist cause in the last decade of the nineteenth century and his failure to act vigorously and effectively when learning the facts of the Nazi

\footnotetext{
1 Robert Donald Shapiro, "A Reform Rabbi in the Progressive Era: The Early Career of Stephen S. Wise" (Ph.D. diss., Harvard University, 1984), 53.
} 
genocide. For the former, clinging to the strong belief that initiatives toward reestablishing Jewish sovereignty, wherever it might be, was an intrinsic part of his Jewish identity, Wise successfully avoided the trappings of dual loyalty by attempting to harmonize Jewish national aspirations with American patriotism. For the latter, Wise's knowledge of the Final Solution by late 1941 and the decision to withhold this information from the press at the request of the U.S. State Department has since fueled debate concerning his actions during the Holocaust. Nonetheless, Stephen Wise's uniqueness as an American Jewish leader lay in his contributions to American Jewish life. First, with the establishment of the Federation of American Zionists in late 1898 to provide help to the first settlements in Palestine, Wise, for the first time, created a modern, efficiently organized political movement among American Jews of diverse denominations. Second, with the foundation of the Free Synagogue in New York in 1907 designed to serve Jews unaffiliated with any synagogue, Wise firmly established the concept of a free pulpit for the American rabbinate and helped to end the practice of 
purchasing pews in American synagogues. Third, the creation of the American Jewish Congress with Supreme Court Justice Louis Brandeis during World War I united within a democratic framework all Jewish groups for common action to press for an autonomous Jewish homeland in Palestine. Lastly, the inauguration of the Jewish Institute of Religion in 1922, later merged into the Hebrew Union College in 1949, crystalized his vision of religious liberalism that adapted the teachings of the Hebrew Prophets to Progressive politics, thus enabling a generation of Reform rabbis to participate in American politics as social activists and community leaders. To be sure, Wise, under the influence of American ideals of democracy and liberalism, moved beyond traditional Judaism to establish a vibrant Judaism that adapted to the new circumstances imposed by American life at the turn of the century. Coined by Wise as Liberal Judaism, this theological formulation proved that the social justice movement was not the exclusive preserve of Protestant ministers but could also be advocated by Reform rabbis, and that the purpose of practicing Judaism lay in 
its universal message to people of all faiths. In other words, the concept of prophetic Judaism which underlies Wise's new religious philosophy meant that the traditional Jewish service would be modified so that social betterment became the core inspiration of its teachings and practices. In some ways the story of Wise is well-known. In In The Life and Times of Stephen S. Wise (1982), the historian Melvin S. Urofsky offered the first biography of the rabbi that covered Wise's life from his arrival in America in the last decade of the nineteenth-century; his ministry in Portland; his unflinching commitment for the establishment of a Jewish State; his long struggle with other reformers to eliminate discrimination against blacks, Jews, labor, women, and other minorities; the formation of the Free Synagogue in New York; and his tireless work on behalf of the Jews in Europe during World War II. The result is a biography that successfully surveyed more than a halfcentury of American Jewish history and revealed the many 
dimensions of one of the most admired and controversial social crusaders in America. ${ }^{2}$

In the general sense, Wise's life mirrored the overall context of the American Jewish experience. Grandson of an orthodox rabbi in Hungary, the son of a rabbi of the Conservative Rodeph Sholom synagogue in New York, and a founder of the Conservative Jewish Theological Seminary in the 1880s, Wise's intellectual and spiritual development that led him to move to outward Reform was lucidly traced by Urofsky. Wise, therefore, as shown by Urofsky, was no less immune to the forces of assimilation that side-tracked many of Jews from orthodoxy to conservatism to reformism because of a radically transformed environment. Having left behind the pious and long established kehillot (Jewish communities) of Eastern Europe, newly immigrated Jews were engulfed by mainstream American culture that diluted their tradition and customs into the melting pot of American values of progressivism and liberalism. The net result was

2 Melvin I. Urofsky, A Voice That Spoke for Justice : The Life and Times of Stephen S. Wise, Suny Series in Modern Jewish History (Albany: State University of New York Press, 1982). 
for many to try on the new, to see what fruits America had to offer.

Urofsky's study of Wise offers a key historiographic insight on how to successfully reconcile American loyalty and Jewish identity amid myriad political, economic, and social changes. Therein certainly lies Wise's true uniqueness. With the surging nativism that condemned the newcomers as different "stock" and the extensive publicity generated by the Zionist cause waged on American soil in the 1890s, American Jews feared of being labeled as racial outsiders. To avoid accusations of dual loyalty, Wise sought to translate Jewish issues as American issues. By portraying the rising tide of anti-Semitism as a betrayal of American ideals and Zionism as a legitimate extension of the America agenda, Wise deflected potential political lightning rods. In this manner, as stressed by Urofsky, Wise molded Americanism and Jewishness into an organic whole by giving Jewish issues American sanction. Urofsky's study of Wise was complemented in 1984 by Robert D. Shapiro in a Harvard History doctoral dissertation, "A Rabbi in the Progressive Era: The Early 
Career of Stephen S. Wise." In stark contrast to Urosfky's biography, Shapiro focused on the rabbi's early career before the 1920s. Shapiro explained that although Wise was raised in a rabbinic home, he was open to progressive ideas and developed a fondness for a secular American culture in which reform seemed influenced by the prophetic tradition. Similar to Urofsky, Shapiro illustrated how the reformist rabbi provided dissatisfied Jews a theology that minimized ritual observances and placed an emphasis on social justice while preaching Jewish nationalism to keep congregants in the fold. ${ }^{3}$

Shapiro noted that Wise's trajectory from orthodoxy to reform espoused the experience of many Jews who embraced American values of progressivism and cultural diversity at the turn of the twentieth century. In this way, he echoed one of Urofsky's themes of the disinfection of American Jews from Jewish identity and practice in an open society. Shapiro explained that Wise's struggle for social justice, his love affair with America, and his religious obligations

3 Shapiro, "A Reform Rabbi in the Progressive Era: The Early Career of Stephen S. Wise", 433. 
toward his people provided a response to this crisis of modern Jewish identity in the United States.

Despite the comprehensive works of Urofsky and Shapiro, scholars and graduate students in the field of American Jewish history have continued to read and write about Wise. This thesis expands upon previous scholarship to focus on the work of Rabbi Stephen S. Wise at Portland's Temple Beth Israel between 1900 and 1906. It explores the ways in which Jewish and Christian thinkers profoundly shaped Wise's commitment to social justice and social progress; Wise's reluctance to come to Portland while the Zionist cause in the East had propelled him to the forefront of the struggle for Jewish emancipation; the intricacies of his involvement on issues related to child labor, temperance, and prostitution; and lastly, the unfinished work on behalf of the Chinese community that muzzled Wise for the first time.

This study, then, combines a review of the literature on Wise and Jewish ideology with archival research on Portland Jewish history. Considering the relatively small size of the Jewish community, it is surprising to discover 
that so much has been collected, organized, and catalogued in several local archival collections. Though Portland resembled many other frontier communities in its economic, political, and social development, the Jews who settled in the city took on a uniquely local character. This thesis points out the similarities and dissonances in the nature and scope of Jewish immigration to Portland, Jewish business and occupational patterns compared to the rest of the country, and the manner in which the established German Jewish community reacted to the arrival of Eastern Jews through the creation of sectarian lodges and other means. Portland's relative isolation and insularity in the early years of the twentieth century made all of the more relevant the work of Rabbi Stephen Wise.

Due to a fire that destroyed the original Temple Beth Israel in December 1923, however, few original primary documents from Wise's Oregon years remain in the Portland area. The main sources of information, consequently, are two collections of the rabbi's correspondence: Personal Letters, edited by Wise's children, Justine Wise Polier and James Waterman Wise (1956); and Stephen S. Wise: Servant of 
the People, selected letters edited by the Protestant clergyman Carl Hermann Voss (1969), supplemented by Wise's autobiography, Challenging Years (1949). This thesis uses these sources to depict Wise's contribution to the domain of social justice and his obsessive struggle to establish a free pulpit. By using the pulpit as a platform for social justice and social progress, Stephen Wise represented a new voice on the religious scene, combining prophetic elements from a penchant for truth telling on public questions with an unflinching commitment to speak out for his people, however defined. 
CHAPTER 1

THE SETTING :

EARLY JEWISH IMMIGRATION TO PORTLAND

\begin{abstract}
More than most other newcomers, they [Jews] brought commercial experience where it was much in demand... When San Francisco, Portland, and their successors were growing most rapidly, they imported much of their food as well as most of their manufactures. Moreover, the kinds of commerce they engaged in were particularly well matched to the skills and resources of Jewish immigrants, including those that merchants immigrants improvised to get started. ${ }^{4}$
\end{abstract}

The main motivation for Rabbi Stephen S. Wise's move to Portland was his desire to spread Zionism throughout the Pacific Northwest. During the summer of 1889, Wise had spoken in San Francisco, Seattle, and Alaska, and while the rabbi was pleased with his success in exposing the plans and purposes of Zionism, Portland was probably the most important single event of his tour. There, Wise addressed a crowd equally divided between Christians and Jews who demonstrated an acute understanding of the zionist cause without holding any concrete program to advance the creation of a Jewish state. ${ }^{5}$ Although, small in size compared to San Francisco or Seattle, the Portland Jewish

\footnotetext{
4 Moses Rischin and Multicultural History Society of Ontario., The Jews of North America (Detroit: Wayne State University Press, 1987).

5 Stephen Samuel Wise, The Personal Letters of Stephen Wise (Boston, : Beacon Press, $1956), 19$.
} 
community counted in its membership familiar figures of regional and national importance. They included Davis Solis-Cohen, a lawyer, merchant, banker, and gifted orator widely sought for his passionate addresses for social justice by both Jewish and non-Jewish audiences; and Solomon Hirsch, the former U.S. Minister to Turkey, often referred to as one of the most ardent proponents in the Pacific Northwest for the establishment of a Jewish state. ${ }^{6}$ While it is true that Portland had a total Jewish population of only 300, Wise calculated that he would be in a better position to attain national recognition for his work by energizing a community that only lacked the proper spiritual and political leadership. The fact that Wise would rise quickly to the top in Portland was largely due to the failure of his former congregation in New York, B'nai Jeshurun, to adequately support its youthful pioneering Zionist rabbis and to the prospect to spread Zionism and social justice in the relative insularity that characterized Portland at the turn of the century. Wise told his fiancee, Louise Waterman, in 1899:

I have tried to be of some service to my people in the East, and not have been afraid to work. It is probably my fault but I have not reached and touched

6 Steven Lowenstein, The Jews of Oregon, 1850-1950, 1st ed. (Portland, Or.: Jewish Historical Society of Oregon, 1987), 60-63. 
and kindled the hearts of people, as the servant of the Lord must needs do, if he is to help them and uplift their lives. I wish to begin work all over again, in a new (religiously) untilled and unexplored land, and I am persuaded that with God's help and blessing, I shall be able to further the cause of Israel and spread the gospel of Zion. Am I not right? ${ }^{7}$

By 1906, Portland had developed into a major population center in the Pacific Northwest. It would grow from a town of 46,000 residents in the last quarter of the nineteenth century to a bustling metropolis of over 200,000 residents in the $1910 \mathrm{s.}{ }^{8}$ Often referred to as the River City of the Pacific Northwest, Portland experienced rapid economic and spatial expansion at the turn of the century. Even though it remained subordinate to other major cities along the Pacific coast in economic and social development, its strategic location on the Willamette River enabled the city to become a major port for shipping timber and agricultural products to San Francisco. Industries such as flour processing, timber mills, and machine shops steadily grew to complement Portland's shipping capacity. International trade also became a secondary but expanding lucrative market for Portland; by the 1870 s its

\footnotetext{
7 Letter to Louise Waterman in 1899, New York. Wise, The Personal Letters of Stephen Wise, 21 .

8 William Toll, "Ethnicity and Stability: The Italians and Jews of South Portland, 1900-1940," Pacific Historical Review 54, no. 2 (1985): 165.
} 
agricultural brokers were shipping wheat directly to London, Ireland, South America, and even Hong Kong. Along with the transcontinental tie via the Northern Pacific Railroad, Portland quickly held commercial supremacy over the cities of Washington State in the first decade of the twentieth-century ${ }^{9}$

With the adoption of the electric street railroad in 1891, Portland's boundaries expanded at a swift pace to challenge San Francisco in economic dynamism and as a cultural center. At a time when few individuals owned cars and taxis were a luxury, streetcars were the most popular motorized means by which Portlanders could travel around the city. Streetcars opened outlying areas to settlement, thus contributing to the slow migration of the bourgeoning middle-class to the fringes of the city and made the city's business district more accessible to residents of nearby communities. ${ }^{10}$ The historian Jewel Lansing explained that streetcars created "a feeling of community" between neighborhoods, as electric trolleys spread rapidly, especially on the east side. Thus Jewish immigrants found

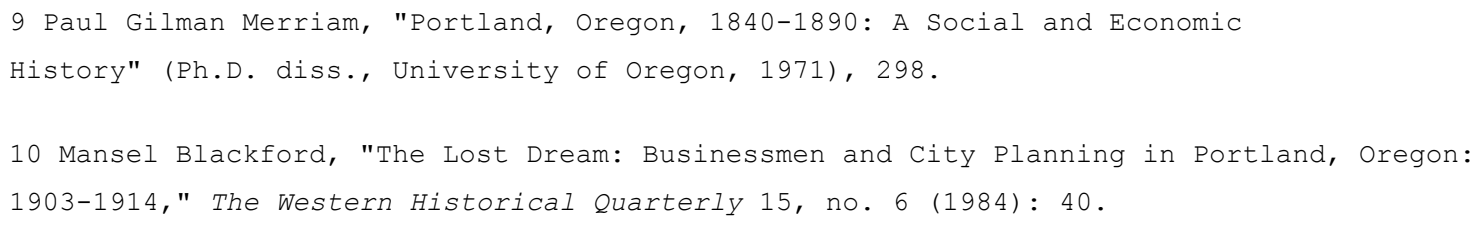


themselves, like their counterparts in the East, thriving in a city which demonstrated a propensity to quickly embrace new technologies as a means to economic development. ${ }^{11}$

Although Portland lacked the heavy industrial and craft venues that spread in many eastern and mid-western urban centers, the River City provided trade-oriented opportunities to newcomers. Thriving on its commercial trade, Portland attracted primarily skilled labor into a well-settled area linked by roads and steamships to a national transportation network. It was therefore in this context of growing development that Portland began to appeal to a large contingent of Jews from both Europe and the East coast. ${ }^{12}$

The first wave of Jewish immigration to the United States occurred between roughly 1820 and 1880 when Jews from Germany, Austria, and Poland left their country for economic and political reasons. First, because of the growing pressure of the Industrial Revolution and the subsequent dislocation of German peasants from their

\footnotetext{
11 Jewel Beck Lansing, Portland : People, Politics, and Power, 1851-2001 (Corvallis: Oregon State University Press, 2003), 196.

12 Carl Abbott, Portland : Gateway to the Northwest (Tarzana, Calif.: American Historical Press, 1997), 51 .
} 
customary lands, the consequences soon made themselves felt: "Jews fell into disfavor with the formerly dominant class of landowners, for whom the rise of the bourgeoisie and the working class meant a relative loss of power, and whose dislike of the liberalism of the bourgeoisie easily turned into dislike of the Jews who served them."13 In Germany, for instance, the Jewish population was essentially divided into three distinct but not exclusive social categories that ranged from street peddlers and artisans to money changers, of which a number were prosperous. One of the most outstanding examples was the Rothschilds, who started their meteoric financial ascension during the period under consideration here. Yet with the European economic downturn of the 1840s, Jewish middlemen and peddlers became the target of the wrath of the German population. Caught up between a flinching economy that depleted the countryside of its population and the introduction and expanded use of the machine to produce goods at cheaper costs, Jewish artisans suffered substantial loss of profits. ${ }^{14}$

\footnotetext{
13 Raphael Strauss, "The Jews in the Economic Evolution of Central Europe," Jewish Social Studies 3, no. 1 (1941): 29. 14 Ruth Gay, The Jews of Germany : A Historical Portrait (New Haven: Yale University Press, 1992), 143-46.
} 
Second, the notorious Bavarian Edict of June 1813 or the Jews Edict, with its residency clause, which limited the number of Jewish families in the places where they lived, had disastrous effects on the German Jewish population. Jews also suffered from the higher taxes levied across the country and the fact that local guilds limited the number of Jews who could be trained by masters. Jews from the lower and middle class ranks found themselves, both legally and economically, in a hopeless situation. Moreover, the turmoil that came in the aftermath of the failed 1848 revolutions translated into a growing German nationalism, resulting in anti-Jewish riots and restrictions on Jewish trading and peddling. Consequently, German Jews who wanted to avoid special taxes and discriminatory legislation often migrated to havens such as Brazil, Argentina, and South Africa; others made the crucial decision to settle in America. ${ }^{15}$

Beginning in the 1820s, trans-Atlantic shipping enabled hundreds of thousands of European Jews from Germany, Austria, and Poland to flee their native lands for America where the Pacific Northwest had become one of the

15 William Toll, "Fraternalism and Community Structure on the Urban Frontier: The Jews of Portland, Oregon: A Case Study," The Pacific Historical Review 47, no. 3 (1978): 376. 
privileged destinations. Although it is not always easy or even possible to differentiate between German Jews and other Germans, one is able to estimate through synagogue records and Jewish lodges that between 1820 and 1880 , out of three million German immigrants, more than two hundred and fifty thousand most likely were Jews. As a result, the Jewish population of the United States increased from about six thousand in 1826 to more than 280,000 by $1880 .{ }^{16}$

Jewish emigration to Oregon did not flow evenly. It leap-frogged from the Missouri River to the shores of California, where a great number of Jews first settled as pioneers in the San Francisco Bay area, as gold mining camps mushroomed across the Sierras. In Oregon, a substantial Jewish population settled near Medford following the discovery of gold in 1851. Downtown Jacksonville, Oregon, features the Brunner Building, the oldest surviving brick structure in town, which was erected in this period by the Jewish Brunner brothers. While most

16 Hasia R. Diner, The Jews of the United States, 1654 to 2000, Jewish Communities in the Modern World 4 (Berkeley: University of California Press, 2004), 79. 
of the Jews left Jacksonville for San Francisco when the gold fever disappeared, a few took residence in Portland.17

To be sure, by the mid nineteenth century, it is likely that there were no more than a dozen Jewish families in Oregon. ${ }^{18}$ While a few claimed land, most came as merchants. A few opened stores across the state but others peddled, moving from place to place, aptly securing an earning through the sale of goods on packhorses. For instance, Aaron Meier, who co-founded the Meier and Frank Department stores, in 1857, had left Bavaria two years earlier to join relatives gold mining in Downieville, California, before starting a vocation as a peddler up and down Yamhill and Clackamas Counties. A decade after opening his first store on Front street in Portland, Meier established one of the oldest retail chains in the Pacific Northwest. ${ }^{19}$

\footnotetext{
17 B'nai B'rith. District no. 4. Portland Lodge no. 65., Commemorating the First Hundred Years of the B'nai B'rith Lodge of Portland, Oregon, 1866-1966 ([Portland, Or., : Heims \& Turtledove., 1966), 5 . 18 H.G. Reissner, "The German-American Jews (1800-1850)," The Leo Baeck institute Yearbook 10 (1965): 57 .

19 B'nai B'rith. District no. 4. Portland Lodge no. 65., Commemorating the First Hundred Years of the B'nai B'rith Lodge of Portland, Oregon, 1866-1966, 4.
} 
Jacob Goldsmith and Lewis May, the first German Jews to arrive in Portland in 1849, also operated as peddlers.20 Simon and Jacob Blumauer followed them two years later, settling in Portland to become prominent figures in the Jewish community and assumed an instrumental role in the establishment of the first Reform congregation, Beth Israel, in 1861.21 The Hirsch brothers arrived in Oregon in 1852 and moved to salem after a short sojourn in Portland to start a profitable general merchandise store and wholesale house. The Selling family, whose son, Ben, established himself in later years as one of the most recognizable social Jewish activists in the Portland Jewish community, settled in Portland in 1862 to open a small store on Morrison Street. ${ }^{22}$

In this manner, German Jews, mostly from Bavaria, built a tight-knit Portland community spawning successful business and philanthropic organizations. The residential

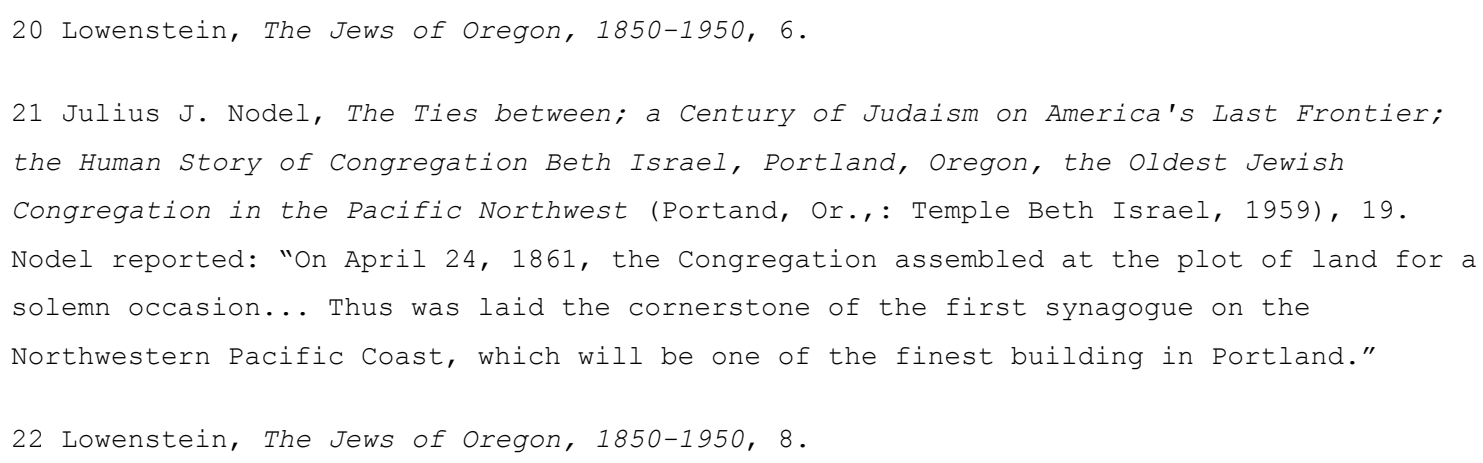


distribution for German Jews showed a clustering on specific streets in the northern part of the city, from $5^{\text {th }}$ and Salmon Street down Park Street to the area near North 16 $6^{\text {th }}$ St. ${ }^{23}$ Available public transportation like street cars made North Portland the ideal place to reside, far enough from downtown yet close enough to places of businesses. ${ }^{24}$ Sharing the same native language other than English and common heritage, Jews quickly developed a particular business model specific to the Pacific Northwest. From Aaron Meier; to Ed Hirsch, elected State Treasurer in 1878; to Bernard Goldsmith and Philip Wasserman, respectively mayors of Portland in 1868 and 1871; Bavarian Jews demonstrated an incomparable success in business and politics. Already in the 1880s, a national Jewish youth newspaper had observed that the Israelites of Oregon, contrary to their brethren in California, appeared to play a lively part in public affairs. With increasing visibility in business and philanthropy, the German Jewish elite not only erected Beth Israel as the first reform synagogue in the Pacific Northwest but also instituted the

\footnotetext{
23 Toll, "Fraternalism and Community Structure on the Urban Frontier: The Jews of Portland, Oregon: A Case Study," 394.

24 William Toll, The Making of an Ethnic Middle Class : Portland Jewry over Four Generations (Albany: State University of New York Press, 1982), 35.
} 
Oregon Lodge, the first B'nai B'rith chapter in the entire region. ${ }^{25}$

Just as German Jews consolidated their place in latenineteenth century American cities, a second wave of Jewish immigration from Eastern Europe inundated the United States. Indeed, between 1881 and 1914, more than two million Jews left Eastern Europe, where life was unbearable due to pogroms, war, expulsion, anti-Semitism, and the high population concentrated in developing cities. ${ }^{26}$ Out of these two million Jews about 80 percent came to the Goldene Medine ("Golden Land" i.e. America). A very large percentage of Jewish immigrants concentrated in New York as hundreds of thousands crowded into the Lower East Side and its peripheries. The vast majority of this migration originated in what was called the "Pale of Settlement" in Russia, which had provided for non-assimilated Jews a legally restricted refuge for more than a century. In the Pale, Jews mostly became intermediaries between the overwhelmingly agricultural Christian population and various urban markets, as noted by the historian Yuri

\footnotetext{
25 B'nai B'rith. District no. 4. Portland Lodge no. 65., Commemorating the First Hundred Years of the B'nai B'rith Lodge of Portland, Oregon, 1866-1966, 1. 26 Gerald Sorin, A Time for Building : The Third Migration, 1880-1920, The Jewish People in America (Baltimore: Johns Hopkins University Press, 1992), 1-2.
} 
Slezkine. ${ }^{27}$ Barred from farming and other agricultural activities by the czarist government, Russian Jews resorted to innovative enterprises such as financial operations and small shops, creating a parallel or "Jewish" economy. ${ }^{28}$ Thus, the life for many Jews in the last quarter of the nineteenth century was concentrated in managing seigniorial manors, running taverns, and collecting taxes. Put in a general way, the structure of the Eastern European Jewish economy involved extraction of money from peasants to the benefit of local lords, thus placing the Jews as intermediaries in charge of levying local taxes. As reported by soldiers who participated in the Russian Campaign of Napoleon in the 1810s, the Jews:

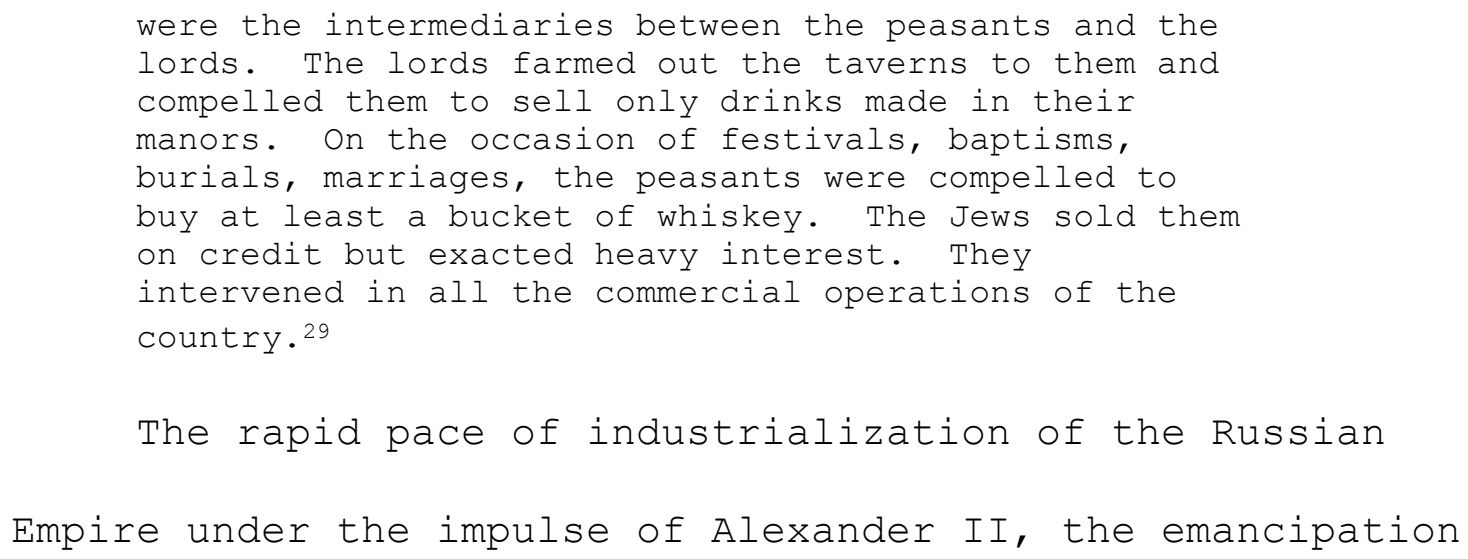

The rapid pace of industrialization of the Russian

Empire under the impulse of Alexander II, the emancipation

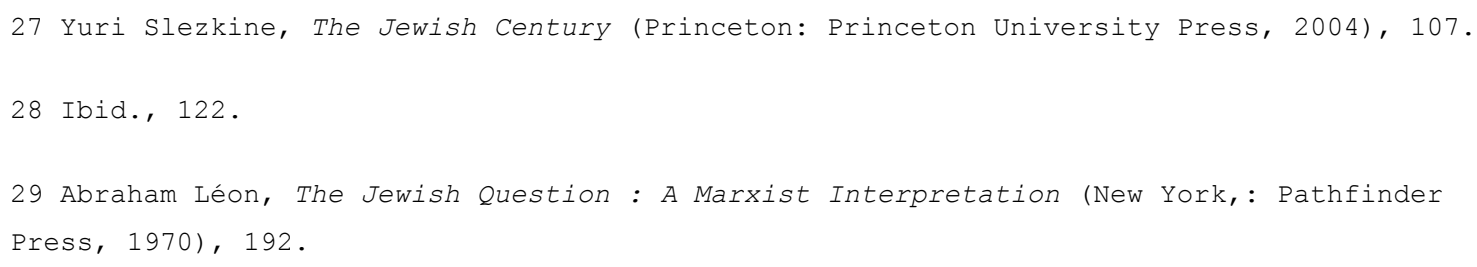


of the serfs, the demise of the manorial economy, and the expansion of the economic role of the state rendered the role of the traditional mediator between the countryside and the town economically irrelevant and increasingly suspicious to the state, leading to the demise of the traditional Jewish economy. ${ }^{30}$ Indeed, the decay of the feudal system and the rapid growth of capitalism in Central and Eastern Europe created new sources for subsistence for landed proprietors who began to attend personally to various branches of production, thus driving the Jews out of business. All of this was exacerbated with the assassination of Alexander II in 1881 by a young radical, which spurred the Russian state to blame the Jewish community and to address the so-called "Jewish question" by fomenting pogroms between 1881 and 1882 that led to the death of hundreds of young Jewish intellectuals and others across the country. 31

Marginalized by the Russian Empire as an enemy of the state during a period of economic and political

\footnotetext{
30 Roger P. Bartlett, A History of Russia, Palgrave Essential Histories. (Houndmills, Basingstoke, Hampshire; New York: Palgrave Macmillan, 2005), 162-66.

31 Zvi Y. Gitelman and Yivo Institute for Jewish Research., A Century of Ambivalence : The Jews of Russia and the Soviet Union, 1881 to the Present, 2nd expanded ed. (Bloomington: Indiana University Press, 2001), 13.
} 
instability, Russian Jews increasingly felt the pinch of paranoia and xenophobia. Fear and hate toward Jews degenerated into repeated violence across the Empire when the Czarist government promoted anti-Semitism by focusing on the role of Jews as middlemen. The turn of the twentieth century witnessed an outpouring of government sanctioned literature and pamphlets promoting the idea of a Jewish conspiracy to dominate the world. The Protocols of the Elder of Zion, published in 1905, as demonstrated by the historian Binjamin W. Segel, sought to deflect peasant discontent and to defend itself against revolutionary criticism by blaming the Jews for the ills of modern moral decadence and financial concentration. ${ }^{32}$

The attraction for many Eastern European Jews of the East Coast through family, religion, and language worked in a similar fashion to attract Jews farther inland and to the West. The spirit of entrepreneurship often associated with Jewish immigrants forged in the shtetl was to give them a decisive advantage to overcome the unfamiliar and often

32 B. W. Segel and Richard S. Levy, A Lie and a Libel : The History of the Protocols of the Elders of Zion (Lincoln, NE: University of Nebraska Press, 1995). 
precarious conditions of their new environment. ${ }^{3}$ Made up of individuals, families, and groups who either moved from the East Coast and had worked themselves up from their original occupations as peddlers to become owners of stores, workshops, and factories, or newly impoverished immigrants from the Pale, local lodges were able to offer a sheltering presence and employment for the new arrivals. In so doing, Eastern European Jews flocked to Portland in great numbers, mostly settling down in South Portland. Situated on the west side between the Willamette River and Fifth Avenue and between Harrison and Curry Streets, South Portland became the residential enclave which offered proximity to downtown but also insularity from mainstream Portlanders. ${ }^{34}$ Indeed, William Toll has shown that Jews from the Pale "settled on a particular neighborhood where the ritual demands of their culture could be satisfied and the anxieties of a pariah people fleeing from pogroms could be assuaged." $" 35$

\footnotetext{
33 For general background on Jewish life in the villages of Eastern Europe from the Middle Ages to the twentieth century see Joachim Neugroschel, The Shtetl (New York: Richard Marek Publishers, 1979).

34 Lowenstein, The Jews of Oregon, 1850-1950, 78. 35 Toll, "Ethnicity and Stability: The Italians and Jews of South Portland, 1900-1940," 171.
} 
Eastern European Jewish families arrived in Portland mainly through two main avenues. The first group, like their German brethren who were trained in the trade sector, found an enclave focused on mercantile pursuits. Often from Odessa, these Jews benefited from the particular location of the city. A major seaport sitting on the shore of the Black Sea, Odessa was a new metropolis whose meteoric rise as a port city of international commercial significance provided a large range of economic opportunities. This promise of economic and social advancement, along with government authorities that encouraged Jews to do commerce by exempting Odessa Jewry of many taxes that crippled other Jewish communities in the rest of the country, inspired many Odessa Jews to participate fully in society. It took a combination of pogroms, the relentless displacement of Jewish craftsman and peddlers as railroads brought factory goods deep into Eastern Europe, and the Russian May Laws of 1892 to prompt the area's Jews to immigrate to the United States in the last quarter of the century. The most notable example was Sam Schnitzer, an immigrant from Russia, who arrived in Portland in the $1900 \mathrm{~s}$ and began his career as a junk peddler. Another example was Louis Albert, often referred 
to as the "Soda Pop King" for his manufacture of a popular Portland punch. Albert landed first in the East Coast in 1906 before permanently settling in Portland later the same year. ${ }^{36}$

A second avenue of migration involved a group of young Jewish idealists from Odessa who founded an agricultural community near Glendale in Southern Oregon in 1882. Led by Vladimir Konstantinovich Heins, a Russian nobleman, better known by his adopted new libertarian American name, William Frey, this new colony was comprised of a self-constituted elite with the aim of building a new society on the land. Under the belief that Jews like every other people could live from the produce of mother earth, the colony, named New Odessa by its members, established itself with the dream of Jewish revitalization through a return to the land. As much as Jews might believe in the spiritually renewing properties of farming life, however, few possessed the mental set or physical fitness required to follow it. Indeed, many were intellectuals who found tilling the soil monotonous, and back-breaking labor. Paralleling the fate of Jewish agricultural colonies in Florida and North Dakota, New Odessa failed, mostly from poor harvests, and 36 Lowenstein, The Jews of Oregon, 1850-1950, 126-28. 
the scarcity of women. ${ }^{37}$ The net result was that not only many Jewish immigrants to Oregon resorted to peddling or other trades that created the foundation for a wealthy Jewish middle class but more importantly, "better than any other single episode, the rise and fall of New Odessa," as Moses Rischin has reported, "signalized the passing of the first era of continentalism and the posting of limits to mass Jewish migration westward by East European newcomers. "38

To explain their rapid social and economic upward mobility, the historian Ellen Eisenberg has demonstrated that Jews of Germany and Russia chose Portland because the city's opportunities matched their own skills. ${ }^{39}$ Peddling at first to learn the tastes of customers in the hinterland and to locate a potential site for a future store, Jews in Portland, as the historian Paul Kriwaczek has suggested, diverted their attention "outwards to provide for the surrounding peoples, expanding their markets to include a

\footnotetext{
37 Leo Shpall, "Jewish Agricultural Colonies in the Unites States," Agricultural History 24, no. $2(1950): 146$.

38 Moses Rischin and John Livingston, Jews of the American West, American Jewish

Civilization Series. (Detroit: Wayne State University Press, 1991), 37.

39 Ellen Eisenberg, "Transplanted to the Rose City: The Creation of East European Jewish Community in Portland, Oregon," Journal of American Ethnic History 89 (2001): 84.
} 
gentile clientele and stimulating economic growth in new industries and novel applications."40 Since most Jewish immigrants hailed from cities and towns, many were craftsmen, petty peddlers, or semi-professionals. While without formal training in their various occupations, they easily adapted to a variety of urban, industrial, or commercial activities. Jews did what millions of other Americans did; they distributed themselves economically, in response to the economic opportunities of the time. ${ }^{41}$ Yet this peculiar distribution of Jews across the United States showed that the West proved to be in general self-selecting in attracting a decidedly youthful, mobile, energetic group of Jews who were already experienced in trade and other commercial avenues, enabling them to rank among the best organized of the newcomers. ${ }^{42}$

In the Pacific Northwest, the specificity of Jewish commercial ventures was also propelled by the Jewish merchandising network, which by the $1860 \mathrm{~s}$ stretched all

\footnotetext{
40 Paul Kriwaczek, Yiddish Civilisation : The Rise and Fall of a Forgotten Nation (London: Weidenfeld \& Nicolson, 2005), 137-38. 
along the Pacific slope. By the constant import of cousins and brothers from across the country and Europe, often first hired as apprentices, an interconnected network of commercial trade in and out of Portland decisively helped the German Jewish community to grow strong and more visible. While older members of the group often had standing in the local community and ties to business networks in Portland and its suburbs, the younger contingent traded from general stores in the hinterland before acquiring the experience and financial safety net to open their own shops.43

Despite the common religious faith and peoplehood of German and Eastern European Jews, nonetheless, a significant degree of antagonism developed between the two. Many of Portland's Jewish leaders of the late 1880s were men of German origins who had "arrived" economically and socially relatively early in the city's history. Now aging and nurtured in a tradition of cautiously protecting the cohesiveness of the German Jewish community, Jewish Portlanders initially demonstrated little inclination to invest in their brethren from Eastern Europe, for they feared indirect repercussions on their own process of

43 Toll, The Making of an Ethnic Middle Class : Portland Jewry over Four Generations, 11. 
assimilation in to the American mainstream. Acculturated German Jews who believed that complete integration was of critical importance cringed at the sheer numbers, somber look, and unfamiliarity with Western tradition that many Eastern European Jews demonstrated during their arrival. They were particularly disturbed at the outrageous manners, often assertive and boisterous, of the newcomers, and their apparent inability to shed "medieval" customs alien to a new social and cultural environment. Further, the use of languages other than English by immigrants or their children threatened national unity in a period in which American nativists insisted that a secure modern state rested on a community of language. German Jews often feared that Gentiles might lump all Jews together and withdraw their friendship and support for their efforts. ${ }^{4}$ From the Eastern European Jewish perspective, the assimilated ways displayed by their German brethren dumbfounded even the most open-minded orthodox Jew. As products of the environment of East-Europe, they made up a community whose way of life was intensely Jewish, and in its own way different from any other community in Jewish

44 John Higham, Strangers in the Land; Patterns of American Nativism, 1860-1925 (New Brunswick, N.J., : Rutgers University Press, 1955), 92. 
history. Tracing their Jewish style-of-life back to Talmudic times, they believed that their own ways were authentically Jewish because they had wholly appropriated the customs, traditions, ethics, and social habits ordained by the ancient, authoritative Rabbinic sages. To some extent, their accommodation to America was more complicated than for others. While the first generation shared the same pains of immigrant transition in facing up to the national, cultural, and religious patterns of the new country, Eastern European Jews had to contend for the very first time in Jewish history with Jewish pluralism. Indeed, the established German Jewish community was already American in everything but religion, and in the eyes of Eastern European Jews, even their religion seemed American, not Jewish.

One way to understand the antipathy felt by many German Jews to their brethren from Eastern Europe is to address the development of local Jewish lodges. The first lodge founded in Oregon was Lodge 65 in 1866. Composed of a mixture of Jews from Germany, Prussia, and Poland, the primary goal was to assist those Jewish pioneers in health and death benefit insurance for surviving family members. In this manner, this first lodge in Portland imitated the 
B'nai B'rith lodges founded in the East Coast in 1843, which sought to help unify the disparate cultural groups in the local community. Toll's examination of the lodges has demonstrated that their members first wished to use the lodge to unite Jews of different backgrounds, to promote self help among fellow shopkeepers and artisans, and finally, to provide a needed health and burial insurance. ${ }^{45}$ In other words, Oregon Lodge 65 had set itself up to promote cooperation between Jews from sometimes-different European origins to implement mutual benefits between ethnic cleavages.

Yet by the late 1880s, as the first generation of German Jews had climbed the social ladder with great success, a younger generation voiced different plans for the lodges. Lodge 65 had been in existence for more than fourteen years and to some extent reflected its aging membership of whom most had established small businesses, and sought social ties and insurance services to complement their business and household positions.46 In response to Lodge 65, younger men who were reluctant to watch their

\footnotetext{
45 Toll, "Fraternalism and Community Structure on the Urban Frontier: The Jews of Portland, Oregon: A Case Study," 380. 46 Ibid.: 381 .
} 
premium paid out in benefits to the families of older members founded the second Portland B'nai B'rith lodge, North Pacific Lodge 314, in 1879. Although the occupational profiles of Lodges 65 and 314 suggested no formally stratified recognizable class lines, since this second generation went into similar clothing and merchandising trades as the members of Lodge 65, this new generation of Jewish entrepreneurs began to attract many white collar employees, especially clerks and traveling agents, between 1880 and 1904. ${ }^{47}$ In other words, while men of Lodge 314 solidified the hold of Jews on clothing and local retailing in Portland, they also sought to depart from their elders by enabling their lodge to attract a new strata of professionals, younger and often employed in different occupations.

A further indication of the ongoing transformation of Portland lodges of the 1890 s can be seen in the establishment of Lodge 416 in 1891. Composed of the sons of wealthy pioneers of German extraction, the lodge represented the successful accommodation of its membership within the Jewish and non Jewish community, an accomplishment that soon outweighed the concern for mutual 47 Ibid.: 384 . 
benefits. ${ }^{48}$ More than 10 percent of members came from the established professions and included physicians, bookkeepers, clerks, and attorneys. At the same time, the Lodge excluded tailors, peddlers, expressmen, grocers, glaziers, and shoemakers. ${ }^{49}$ The magnitude of Russian immigration to Portland between 1885 and 1915 further accelerated the growing gap between lodge missions. Relinquishing the idea of incorporating this new wave of immigration into their ranks, Portland Lodge 416 preferred to work briefly with Lodge 314 to mount local relief efforts for Jewish newcomers, and contributed to the Neighborhood House, a settlement organized by the Local Council of Jewish Women to provide kindergarten services and homemaking classes for immigrant women.50 It was not until 1897 that the Eastern Jewish community was able to create its own lodge, Sabato Morais Lodge 464.

The lack of enthusiasm among German Jews to integrate Russian brethren in their cultural institutions mirrored the general malaise that struck America at the turn of the century. The portents were not good. The coming of the

\footnotetext{
48 Ibid.: 389.

49 Ibid.: 390. 50 Ibid.: 395 .
} 
Jews from Eastern Europe coincided with a rapid growth in nativist sentiments. In his study of anti-Semitism in America, the historian Leonard Dinnerstein has stated that the influx of East European Jews at the turn of the twentieth century had an unsettling effect on ordinary Americans based upon the premise that Jews were not AngloSaxons and consequently thought to be unassimilable. ${ }^{51}$ As a result, the Jewish German elite of Portland feared that these newcomers would interfere with their headlong drive to achieve middle-class respectability. Moreover, they squirmed at the perspective of being touted with dual loyalty as the migration of Eastern European Jews included young intellectuals exposing radical ideas like Socialism or Zionism. While Lodge 416 grew wealthier and its member considered requests for charitable contributions from Jewish and nonsectarian sources, they sought to alleviate the lot of their Eastern brethren by sponsoring subsidiary lodges to provide shelter and financial aid, thus preventing any threat to their fragile assimilation into the American elite.

51 Leonard Dinnerstein, Antisemitism in America (New York: Oxford University Press, 1994), 59 . 
In this manner, consolidation of Lodge 416 and other benevolent societies concealed as much as it revealed about changing communal values. These consolidators, of course, did not have petty motives; rather as a new elite they held beliefs they felt would benefit the community. Under such circumstances there was little social mingling between the two groups, and the cultural and social clubs of the "uptowners" were off limits. "The Portland Jewish community had never been unified," noted historian William Toll, "particularly after the influx of immigrants from Prussia and the Posen area of Poland but by the time a generation of wealthy American-born and educated men and women came to share a nominal Jewish identity with more traditional eastern European, the social divisions were as acute as the culture difference."52 Yet amidst such group tensions the desire to "Americanize" the immigrants and certainly a residual feeling of the K'lal Israel, the community of Israel, caused an outpouring of charitable aid from the established Jewish community. In other words, organized charity became a principal bridge between the "uptown" and "downtown" wings of the Jewish community.

52 Toll, The Making of an Ethnic Middle Class : Portland Jewry over Four Generations. 
When Rabbi Wise arrived to Portland in the fall of 1900, social divisions on the Jewish community reflected the general dichotomy across America: "uptown Jewry" was ethnically German and "downtown Jewry" was ethnically East European. The distinctiveness between the two groups was also present in their religious expression: "uptown Jews" were religiously Reform and non-nationalists while "downtown Jews" were religiously Orthodox or non-Orthodox Jewish nationalists.

In summary, this first chapter has first sought to depict Portland before and after 1900 to lay the foundations to understand the social, economic, and cultural background in which Jews from German and Eastern European extraction came to envision a new life in the Rose City. The strategic location of Portland in the Pacific Northwest thus explains how this western city attracted a distinctive Jewish demography. Jews who came West either had higher skills in trade or family support to initiate small business ventures. Peddling and later retail stores provided access to the professional occupations for Jewish immigrants. Lastly, although German and Eastern European Jews shared a common faith, their tradition and cultural markers fostered significant distinctions. While German 
Jews longed for "Americanization" and active participation in American public life, Jews from central Europe progressed consciously at a slower pace; thus, determined to not simply adopt the models set out for them by their brethren, but to forge new lives in their own way 


\title{
CHAPTER 2
}

\section{THE MAKING OF A SPIRITUAL LEADER}

\begin{abstract}
The period of his first ministry at B'nai Jerushun can thus be seen as a growing period for Wise, a time in which he sorted out his ideas and dreams while making himself into an effective rabbi and preacher. ${ }^{53}$
\end{abstract}

On March 17, 1874, a second son and second child, Stephen S. Wise, was born to Aaron and Sabine Weisz of Erlau in the Austro-Hungarian Empire. His father, Aaron was ordained rabbi in 1867 in Hungary under Reb Israel Hildesheimer in Eisendadt. Aaron grew up within a community in which the prominent Weisz family had been rooted for several hundred years in which almost every son was a rabbi. The most famous of Stephen's ancestors was his grandfather, Reb Joseph Hirsch Weisz, who was the Chief Rabbi of Erlau, a small town near Budapest, until his death in 1881. Joseph, often described as forceful and spirited in his defense of Orthodox Judaism, came under attack when the revolution of 1848 hastened Jewish emancipation and the grant of full civic rights in 1864. Liberalism was also challenging orthodoxy on the religious scene. Here the conflict for control of the Jewish community pitted the young Reform movement against entrenched Orthodoxy. The

53 Urofsky, A Voice that Spoke for Justice : The Life and Times of Stephen S. Wise, 11. 
historian Melvin Urofsky has indicated that Reb Joseph stood against the currents of change that swept through many of the synagogues of Hungary, setting himself firmly against any reform by insisting that "the word of G-d, as given to Moses and interpreted by the rabbis, could not be altered to suit the convenience of Jews too lazy to obey the law."54 The reaction of religious reformers against Orthodoxy in general and in particular towards Reb Joseph was as brutal as Rabbi Joseph's often-fanatical defense of Orthodoxy. For a short time, in fact, the reformers had the upper hand in forcing Reb Joseph and twenty of his peers to resign from their pulpits.

The deposed rabbis brought their case to the civil courts, hoping to secure a court ordinance to reinstate them to their respective congregations and pay back their salaries. The matter dragged on for more than twelve years before resulting in a judgment in their favor. Their salvation came ironically from the Church led by the Catholic primate of Hungary, Archbishop Bertescovitch, and from Emperor Franz Joseph. The former testified to their unflagging loyalty to the crown while the latter expressed sympathy for them. Yet Joseph's pulpit was saved only for 
a brief moment, for in the aftermath of the failed Revolution, he was charged with sedition when several Jews, who sought to dust away many of the traditional ways that they considered archaic and irrelevant, charged that he had allegedly aided opponents of the crown. At the trial, Catholic leaders reiterated his loyalty to the crown, thus preserving his ministry and rescuing him from certain imprisonment. Even though Reb Joseph retained the post of chief rabbi in Erlau until his death, the strife over reform left him at odds with the general reform wind that blew across the country. In the last years of his life, he became a recluse at his home, only officiating on major holidays. It was there that he taught his son, Aaron, the foundations of Judaism. ${ }^{55}$

There is little doubt that the religious battles waged within Hungarian Jewry in the second half of the nineteenth-century between Progressives and the strictly Orthodox trickled down into the Weisz family in ways that Reb Joseph could not have predicted. Joseph's son, Aaron, although ordained within the Orthodox community, anticipated a departure from Chassidic tradition that prioritized religious over secular studies when he pursued 55 Ibid., 2. 
graduate studies in Berlin and Leipzig, receiving a doctorate from the University of Halle for a dissertation on angels and demons in rabbinic literature. Despite his father's heritage, Aaron's values and behavior traits were shaped significantly by what he had absorbed from the Emancipation movement which spread from Germany eastward to Hungary, Bohemia, Galicia, Russia, and Poland. Upon hearing the news of the assassination of Abraham Lincoln in 1865, Aaron developed a longing for America that dramatically changed the course of his life. After completion of his doctorate in 1870, he returned to Erlau where he married Sabine De Fischer Farkashzy, the heiress of the great Herend porcelain family business. Sabine's father reluctantly gave her hand to Aaron only under the condition that he would enter the family business, thus leaving the rabbinate for a more comfortable financial and social position. ${ }^{56}$

Sources for the story of Aaron's emigration to America are admittedly scant. No single factor or combination of events, except Aaron's role on a laborer's strike after exposing the horrible working conditions and tyrannical treatment in his father-in-law's factory, may explain the 
young man's motivation to leave his native land for America. To be sure, his departure was certainly prompted by a desire to start a new life in the Golden Land. Like many other Jews from the first and second wave of Jewish European immigration to the United States, Aaron first traveled alone to New York City. During the immigration process at Ellis Island, Weisz became Wise as Jewish names were often transliterated from the Cyrillic or Hebrew alphabet into English. His first job was as a bricklayer for the Tribune Building being constructed on New York's Park Row. After a few months of employment in construction, Aaron was hired to become assistant rabbi at Beth Elohim in Brooklyn. Two years later, he was appointed head rabbi of Temple Rodeph Sholom, Manhattan, an office he held until his death in 1896. Sabine subsequently followed Aaron to the United States almost two years after his departure, accompanied by their two children, Otto Irving and Stephen Samuel. ${ }^{57}$

In the fall of 1875, the Wise family took residence on East $5^{\text {th }}$ Street on the Lower East Side of Manhattan while the Rabbi served as the spiritual leader of Temple Rodeph Sholom. At this time, the congregation was struggling to 57 Ibid., 3. 
reconcile its identity between orthodoxy and outward Reformism. Aaron Wise successfully guided the temple's journey to adopt a more moderate religious stance consistent with what would become known as the Conservative movement. His work culminated with the establishment of the Jewish Theological Seminary in the last decade of the nineteenth century, destined to become the cornerstone of Conservative Judaism in the United States. The school opened a totally unanticipated new chapter in American Jewish history by providing rabbinic programs that initially seemed to speak to the more numerous and still rapidly growing Eastern European population. Unfamiliar with the culture of modernity presented to them upon their arrival in the Goldene Medine, the Seminary's combination of Jewish traditionalism with an American perspective served the new Eastern European community. ${ }^{58}$

Stephen wise began his intellectual training at the City College of New York at thirteen. Fifteen years later, in 1902, he earned a doctorate from Columbia University for his translation of Solomon ibn Gabirol's eleventh-century treatise on ethics, The Improvement of Moral Qualities.

58 Neil Gilman, Conservative Judaism : The New Century (West Orange, N.J.: Behrman House, 1993), 39 . 
Following his father, who had completely severed ties with Chassidism when immigrating to America, Stephen was poised to parallel the same intellectual and religious trajectory. Under Rabbi Alexander Kohut, who actively participated in the founding of the Jewish Theological Seminary in the 1870s, stephen pursued secular studies while continuing his study of Hebrew and Jewish topics with his father. At Columbia, his mentor was none other than Professor Richard J. Gotthiel, who was instrumental in the formation of the University's Semitics Department. In this manner, stephen Wise's religious and academic training was fashioned by the same imperatives that had guided his father, who had declared upon his arrival in America that orthodoxy as experienced in Europe was "inappropriate" in the New World. ${ }^{59}$

Although the Conservative Theological Seminary heavily influenced Stephen Wise, he took things a step further and went on to identify himself with the tenets of Reform Judaism. Both Conservative and Reform movements developed in tandem in the early nineteenth century in response to the modern demands of American life that directly conflicted with traditional European Judaism. Its first

59 Urofsky, A Voice That Spoke for Justice : The Life and Times of Stephen S. Wise, 3. 
manifestation was the South Carolina's Charleston Reform experiment of the 1820s which called for an abbreviated service, vernacular prayers, a weekly sermon, and an end to traditional free will offerings. ${ }^{60}$ There is little doubt that this first trial planted the seeds of change in traditional Judaism by implementing a religious discourse that would better parallel American Protestant culture. Reform Jews thus introduced a plethora of innovations that dramatically disregarded traditional Jewish law by including organ and choir music into the Sabbath services, mixed seating of men and women, the elimination of anachronistic prayers, and the abandonment of the traditional skullcap and prayer shawl. The resulting effect of these innovations was twofold. First, it fueled growing conflict amongst synagogues causing splits and secessions within American Jewish life. Second, it contributed to a revitalized Judaism by producing a religious revolution that replaced a monolithic Judaism with one that was much more democratic, free, diverse, and competitive. ${ }^{61}$

60 Jonathan D. Sarna, American Judaism : A History (New Haven: Yale University Press, $2004), 54$.

61 Ibid., 61 . 
The arrival in America of Rabbi Isaac Mayer Wise (not related to Stephen Wise), one of Europe's leading Jewish scholars, in the fall of 1846, strengthened the hand of the reform camp. Born and ordained in Bohemia (now part of the Czech Republic), Isaac Wise undoubtedly was attracted to what America had to offer in the domain of religious freedom. Armed with effective oratory skills, both in German and English, mastered in a matter of months, and intellectual muscularity, entertained by long hours of self-study, Wise managed an integration into the American mold with expediency and great fervor, leading to his innovative tenure as rabbi of Congregation Beth-El in Albany, New York, in the early 1850s.62

Although adamant about the sanctity of Shabbat at first, wise quickly became overwhelmed by the openness of American life. Accordingly, he picked up on the work left in Germany and sought to deconstruct traditional Judaism to appeal to American Jews more interested in economic and social achievements than Jewish observances. In 1866, for instance, the rabbi initiated a late Friday evening shabbat service to accommodate worshippers who had to work on

62 Max Benjamin May, Isaac Mayer Wise, the Founder of American Judaism : A Biography (New York: G.P. Putnam's Sons, 1916). 
Saturday. He also issued a new prayer book, Minhag America (The American Rite or daily Jewish prayers book) that emphasized vernacular language over Hebrew and in which allusions to a return to zion and to the Messiah were abandoned. Following this, a delegation of Reform rabbis gathered in Pittsburgh in 1885 to ideologically ground the tenets of Reform Judaism. Those present included Rabbi Gustav Gottheil of New York's Temple Emanu-El, who for many years diligently worked to emphasize social justice and social progress in Judaism; David Einhorn of Baltimore's Har Sinai Temple, often described as an ultramodernist who stood on the fringe of Reform Judaism and looked for new ways to downplay ritualism and talmudism; and Kaufman Kohler, of Emanu-El Temple, who initiated the gathering to formulate a coherent Reformist program. ${ }^{63}$

The outcome of the Reform convention was revolutionary. Its official declaration described progress and reason as the fundamental tenets of Judaism in which exile, eschatology, law, and revelation were reinterpreted while the new mode of service in the Reform temple was hushed and decorous, using little of the ancient Hebrew prayer book. Certainly some of these changes made Jewish 63 Sarna, American Judaism : A History, 144-51. 
life look more Christian. The organ music, the new synagogue architecture, the regular sermon, eating in the same restaurants with non-Jews; all aimed to create a common religious experience in which Jews and Christians could freely relate. But all of this was not due to a desire to be less Jewish. On the contrary, the conversion to American life was intended not to lean toward Christianity but instead to re-construct the Jewish faith. Although these changes and modernization of the ritual outraged orthodox Jews, the Reform movement insisted that Judaism was not a system of concrete law, but a living doctrine made to evolve with modern life. New social conditions in America made such an emphasis on traditional prayers and commandments, as well as the faintest expression of return of Zion, obsolete, if not an obstacle, to the themes of social justice and social progress.

The Reform movement benefited from the fact that this new wave of rabbis of German origins turned out to be of different breed. They were not only ordained at established Central European seminaries, thus recognized by their local authorities as well as the greater Jewish community, but in addition to their rabbinic ordination, most of these newly immigrated rabbis possessed graduate 
degrees of which a sizable number even possessed doctorates. Thus, their understanding of Judaism and daily rituals in their respective communities in Europe were already tainted with secular tones before settling in America. Often referred to as "Reverend Doctors" because of their sheer intellectual understanding of the Torah, their commitment to liberalism and social activism came as no surprise. ${ }^{64}$

Felix Adler, for example, who graduated from Columbia and was ordained in Germany, went on to earn a doctorate at Heidelberg at the age of twenty-three, thus exemplifying the changing nature in the rabbinic tradition. Upon his return to New York in 1871, Adler produced one of the first sermons at Temple Emanu-El that set the tone for further liberal, if not radical, discourses on the fringe of Reform Judaism. In tones that prefigured arguments to be made a generation later by Rabbi Stephen Wise, Adler's sermon titled "The Judaism of the Future," delivered before a bemused congregation, offered a tirade on justice, peace, and goodwill that contained not a single reference to G-d. This sermon was so powerful that stephen wise would subsequently write a letter in early 1900 to his future 
wife, Louise Waterman (married on November 14, 1900), in which he stated that he would "interpret the message of Ethical Culture to itself and to my people."65

Setting himself apart from current views of Reform Judaism that still addressed G-d as a dynamic force in human life, Adler appeared to dismiss the notion of a personal deity. Instead, upon his acceptance of a professorship at Cornell University in 1874, Adler refined his views on Judaism in a new movement by revealing certain ethical truths that alone sufficed to elevate mankind to justice and righteousness. A year later, Adler founded New York's Society for Ethical Culture, which proposed to teach a religion of morality in which $\mathrm{G}-\mathrm{d}$ is replaced with a moral idea and Humanity is the primary actor in transfiguring evil into good, and chaos into order. ${ }^{66}$ At the same time that Adler made his impact on liberal religion, several prominent Protestant clergy developed a similar socially inspired agenda termed the Social Gospel Movement. Led by the liberal theologian Walter Rauschenbush, the Social Gospel applied Christian ethics to

65 Wise, The Personal Letters of Stephen Wise, 34. 66 Felix Adler and Leslie Willis Sprague, The Religion of Duty (New York.: McClure, Phillips \& Co., 1905), 9. 
social issues, especially poverty, inequality, liquor, abuse, slums, poor hygiene, child labor, and inadequate schools. ${ }^{67}$

Rauschenbush encouraged the movement and its members to embrace the downtrodden and to actively engage in social actions. Such a focus complemented the approach of several Reform rabbis, including Emil Hirsch of Chicago's Sinai Temple, who enthusiastically worked on Jewish and municipal causes. Most often recalled for his frequent outbursts against white slavery among immigrant Jews, Hirsch combined the Jewish prophetic tradition with the causes of social reconstruction. In this manner, Hirsch's teachings paralleled the Social Gospel movement in its concern with the now rather than the hereafter; with social justice rather than salvation; and with the spirit, rather than the letter of religious law. Hirsch preached that the prophetic G-d is one who loves, a G-d who is known and concerned with man. In other words, the prophet was not concerned with theological or doctrinal matters but with the well-being of the poor. In Emil Hirsch's terms, the prophet insisted that man must be devoted above all to the

67 See Jacob A. Riis, How the Other Half Lives; Studies among the Tenements of New York, American Century Series, S-12 (New York, Sagamore Press, 1957), 1-51. 
welfare of his fellow man and not waste time trying to

unravel ultimate questions. As he declared in a sermon in February 5th, 1899 :

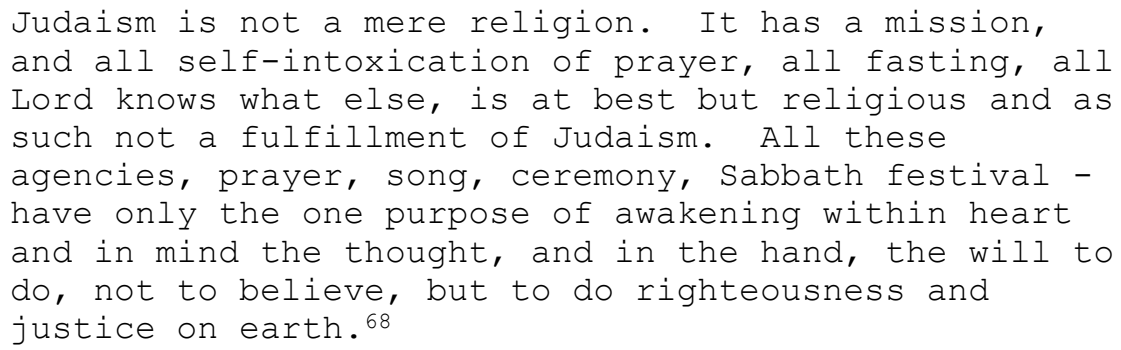

The prophetic tradition Hirsch cited had appeared

between the ninth and seventh centuries B.C.E in response

to the establishment of the first Jewish monarchy in

Palestine and the evils of a centralized state such as

heavy taxation, arbitrary power, corruption, and fear. In

response, the prophets launched a new vision of Judaism

that branded the concept of right and wrong over cultic

practices. The theologian Abraham Heschel discussed at

length the Jewish concept of these biblical prophets who

spoke truth either derived from divine inspiration or from

moral conviction, even when that truth was socially

detested:

The image of the prophets was that of preachers of

morals and spiritual religion as opposed to ceremonialism and ritual... The preoccupation with justice, the passion with which the prophets is

68 Hirsch, Emil G. "How Far are we the Chosen People?" In The Jewish Preacher: Rabbi Emil G. Hirsch, Ph.D., Ll.D., compiled and edited by Myron A. Hirsch (Naples, Florida: Collage Books Inc., 2003), 221. 
rooted in their sympathy with divine pathos. The chief characteristic of prophetic thought is the primacy of G-d's involvement in history. History is the domain with which the prophets' minds are occupied. They are moved by a responsibility for society, by sensitivity to what the moment demands. 69

In brief, the prophets established a moral tradition that would advance the cause of social justice by confronting the people and their ruler rather than foretelling the future or of predicting the Messiah's appearance. The nearly two thousand-year gap between the inception of Judaism and the nineteenth century was relatively inactive, though not devoid of prophetic figures. It was then in nineteenth-century Germany that prophetic Judaism found new adepts. Rabbi Abraham Geiger, for example, who sought to remove all nationalist elements such as the "chosen people" claim from Judaism, developed the idea that prophetic religion not only illustrated the genius of the Jewish people by helping Judaism evolve toward universalism and messianism but also could be conducive to address social justice in relevant contemporary terms. To support the concept that connected prophetic Judaism with social justice, it was imperative to seek a medium to carry on the new mission. Although the prophets of ancient Judaism

69 Abraham Joshua Heschel, The Prophets, [1st ed. (New York, Harper \& Row, 1962), 218-19. 
To appropriate the tenets of prophetic Judaism in America, the Reform movement utilized sermons as a vehicle for instilling social progress and social justice. Consequently, the sermon took a more prominent place in the religious service. The first generation of rabbis, largely of German extraction, had already attempted in Germany to incorporate sermons as a standard feature during services. America now offered the unprecedented opportunity because of its lack of rigid social and religious structures to establish the sermon as the trademark of the Reform movement. By the 1880s and 1890s, as Naomi W. Cohen has suggested, "the sermon had become a standard feature of traditional services and English was rapidly supplanting German as its language."72 The Jewish sermon in its original form had related mainly to the Torah portion of the week and never reflected social or political issues. ${ }^{73}$ It is not until the influx of German Jews to America that sermons profoundly diminished their exegetical impulse and shifted away from Torah commentary. From now on, the major

\footnotetext{
72 Naomi Wiener Cohen, What the Rabbis Said : The Public Discourse of Nineteenth-Century American Rabbis (New York: New York University Press, 2008), 3.

73 Nathan W. Kaganoff, "The Traditional Jewish Sermon in the United States from Its Beginnings to the First World War" (Doctoral Dissertation, American University, 1960), 32.
} 
focus of the Reform service was a rather lengthy lecture or address on social and political matters delivered by the rabbi .

This emphasis on a dynamic sermon was to some extent the result of the rapid assimilation of the second generation of American German Jews. The synagogue, which had been for generations of Jews the core of social and religious life, was now perceived as an artifact of the past. Had the Jewish sermon not been revitalized and rejuvenated in its content and forms, and sometimes given primacy over liturgy, one may speculate that the Reform movement itself would have found it difficult to lure disaffiliated young American Jews of German descent back to membership. Some of the underlying challenges in attracting these young American Jews to the synagogue were that in the free environment of the nineteenth-century, Yiddishkeit (Jewishness) was increasingly pushed aside as more and more Jews were intermarrying or otherwise leaving the fold. In addition, many second generation American German Jews were revolting against their religious ancestors. As a result, the content of the sermon preached before congregations began to espouse the realities of the social, political, and economic environment presented by 
the particularities of the American setting. The sermon steered the movement from traditionalism by making Judaism harmonize with the ethical aspirations of western civilization

With the economic crisis of the 1890s, the United States was ripe with social issues that ranged from the spread of slums in crowded cities to embittered unionism to the incessant influx of poverty stricken immigrants. "Increasing in complexity as well as in size, American cities teemed with poverty, slums, political corruption, and countless other anomalies," one historian has suggested; "the incongruities in American life were shocking."74 This unprecedented crisis in scale and nature forced a whole generation of wealthy business entrepreneurs that had tasted the fruits of success to become more responsive to social justice. Under the rubric of Progressive reform social and political activists in the East and elsewhere began campaigning heavily to create a mood of responsibility among business leaders and professionals. Yet while the country was in turmoil, no

\footnotetext{
74 Leonard J. Mervis, "The Social Justice Movement and the American Reform Rabbi," in Critical Studies in American Jewish History; Selected Articles from American Jewish Archives, ed. Jacob Rader Marcus and American Jewish Archives. (Cincinnati, : American Jewish Archives, 1971), 121.
} 
tangible initiative was taken by the Reform's Central Conference of American Rabbis to alleviate the dire conditions of many Jews and non-Jews alike. It was not until the 1920s that the confederation would take two timid initiatives: one favoring cooperation with the Golden Rule Brotherhood, a peace organization; the other condemning child labor. In other words, although these topics would be debated and engaged within weekly sermons, substantial social activism never gained ground among Reform rabbis. "The rabbis in 1885," concluded historian Leonard J. Mervis, "were not prepared to confront immediate evils with a message of justice and righteousness. More and more they concerned themselves with social problems, but in a manner that was idealistic and utopian."75

It was during this period of social turmoil in America that young Stephen Wise traveled to Vienna to pursue his rabbinical training under the mentorship of Rabbi Adolph Jellinek. Although Wise arrived with prior experiences gained from his secular studies and his father's commitment to social justice, it was in Vienna that Wise learned that "a rabbi"s sermons need not be limited only to Jewish

75 Ibid., 118. 
themes."76 The rabbi was therefore no longer limited to conducting religious services and the weekly Torah discussion, but instead could use ancient Midrashic texts and adapt them to contemporary Jewish problems. ${ }^{77}$ Thus, nurtured by the philosopher Thomas Davidson, Reverend Walter Rauschenbusch, and Rabbi Adolph Jellinek's preoccupation with social and economic issues, Wise embraced social causes and became one of the first recognizable rabbis to develop social Judaism in America. Wise returned to New York in the spring of 1893 not only with his rabbinic ordination conferred by Rabbi Jellinek but with the possibility of a pulpit awaiting him in the Congregation of his father. Instead, Wise took a position in the large $\mathrm{B}^{\prime}$ nai Jeshurun congregation, on Manhattan's Madison Avenue. During this period, Wise became a pioneer in the transition from social discussion to social activism through the implementation of a series of new organizations that encouraged the active participation of young Jews, women, and seniors in the Jewish and nonJewish community. First, Wise initiated a Sisterhood group

\footnotetext{
76 Urofsky, A Voice That Spoke for Justice : The Life and Times of Stephen S. Wise, 10. 77 Kaganoff, "The Traditional Jewish Sermon in the United States from Its Beginnings to the First World War", 68.
} 
with the help of the women's congregation to provide relief for some of the victims of the harsh winter that hit the East Coast in 1893. Second, to encourage young Jews in synagogue activities, Wise founded a Society for Religious Study, which called for scholars and community leaders to discuss diverse topics. Finally, it was also during those early years of ministering that Wise began to extend his activities outside the congregation. He led the organization of the Jewish Religious Schools Union in 1896, served as director of the Hebrew Free School Association, and was elected in 1899 as secretary of the state Conference of Religions. In the latter capacity, he laid the ground work for one of his primary occupations, interfaith activities, at his next position as chief rabbi at Temple Beth Israel in Portland, Oregon.

Congregation Beth Israel had been founded in 1858 and was once one of the largest congregations in the Pacific Northwest. Composed of about eighty families of German origins, the congregation's existence was the result of the need of a Jewish cemetery in the Portland area. As Rabbi Julius J. Nodel noted, "In Portland, it was also the thought of death that provoked the first manifestation of organized Judaism." Thus, prior to the Temple's existence, 
local Jewry had founded the Mount Zion Cemetery Association of Oregon in 1856 at a time when disease, fire, Native American attacks, and the hardships of daily existence took the premature lives of Jewish pioneers alike. In this inhospitable environment, Samuel M. Laski, the first rabbi to officiate at Beth Israel, had not been ordained. Instead, he was a layman who reflected a time where Jews who immigrated to America often possessed sufficient knowledge in the field of Jewish tradition, Hebrew, and the qualities of Jewish leadership to assume the positions of Minister, Chazan (cantor), and Shochet (ritual slaughterer) $\cdot{ }^{78}$

It took five years for Temple Beth Israel to lure an ordained rabbi to Portland who demonstrated enough confidence in himself to brave the developing yet still isolated trading center in the emptiness of the Oregon Territory. Rabbi Julius Eckman of San Francisco, who mixed conservatism with a dash of early reformism, answered the call and began to officiate in Portland in July 1865. To be sure, the congregation was already leaning toward reformism under the impetus of a German Jewish membership

78 Nodel, The Ties between; a Century of Judaism on America's Last Frontier; the Human Story of Congregation Beth Israel, Portland, Oregon, the Oldest Jewish Congregation in the Pacific Northwest, 12. 
reaching upper-class status. The hiring of Eckman showed evidence that the Board of Trustees of Beth Israel was looking for ways to innovate while at the same time ensuring that the process would not alienate the old guard. "In the free atmosphere of America," explained Nodel, "it was impossible to ignore the faint stirrings of reform that reached the attention of the immigrants."79 Put simply, the blind desire to blend into the American melting pot was stronger than the ritual and tradition that had cemented communities in Old Europe for centuries. America offered new opportunities as well as new challenges that made it somewhat impractical to hold to the spirit of Orthodoxy. For instance, the laws of Kashrus and Sabbath restrictions proved particularly difficult to sustain for many Jews in the pioneer communities of the West.

The steering of Beth Israel to Reform Judaism came decisively under Rabbi Moses May, who from 1872 to 1880 applied himself to eradicate the last vestiges of Orthodoxy in the congregation. Charismatic, enthusiastic, forceful, and relentless in his attempt to convert the congregation to the merits of Reform, May was described by Nodel as "the

79 Ibid., 31. 
most controversial figure ever to occupy the pulpit"80 before Wise. May introduced the first Minhag American to his congregants in 1872, thus enabling a minority yet growing portion of the congregation to fully embrace the tenets of Reform Judaism. Yet the new prayer-book, written and prepared by Dr. Isaac Mayer Wise to unify all American Jews around a common liturgy, prompted waves of heated debate between the ranks of the first generation of German Jewish immigrants and their children.

Swaying back and forth between Orthodoxy and Reformism, and under new circumstances imposed by the standards of American life, the congregation Beth Israel succeeded in bringing together professional social and educational agencies that counterbalanced a lack of decisiveness about its religious direction. For example, The First Hebrew Benevolent Association of Portland was founded following the establishment of the congregation to help new Portland Jewish arrivals, often disoriented and sick. Months later, The Hebrew Ladies Benevolent Society enabled wives and mothers to organize a flexible group that focused on the family and children through education and

80 Ibid., 24. 
offered a means of autonomy from male control.81 Amid these social agencies, several rabbis preceded the arrival of Rabbi Stephen Samuel Wise on September 1, 1900.

Despite an early unofficial commitment to Temple B'nai Jeshurun of New York, Wise took a leap of faith to move to Portland. In New York, Wise had become a well-known figure not only for implementing a wave of changes at $B^{\prime}$ nai Jeshurun but because of his fervent commitment to the Zionist cause. By the 1890s, Wise had become an impassioned Zionist and a devoted supporter of Theodor Herzl. Often referred to as the most outspoken Zionist on the East Coast along with his mentor, Professor Richard Gottheil, Wise did not anticipate the move to Portland with enthusiasm, but fretted over the important work still to be done for the creation of a Jewish state. Wise's untiring work for the Zionist cause led his circle of friends to be concerned when they learned that he contemplated moving to a rugged and developing town at the other end of the country. Even his mentor, Richard Gottheil, expressed fears that Stephen would waste his life in Oregon. ${ }^{82}$

\footnotetext{
81 Toll, The Making of an Ethnic Middle Class : Portland Jewry over Four Generations, 48. 82 Urofsky, A Voice That Spoke for Justice : The Life and Times of Stephen S. Wise, 30.
} 
Although Wise expressed mixed feelings about Portland, he also hoped that the city's relative isolation could make it the ideal place to foster the spirit of Zionism. He shared with Theodor Herzl his hope of extending Zionism westward in November 28, 1899:

I presume you have heard that, in the summer of the next year, I am to take up my residence at Portland, Oregon, which is on the Pacific coast some 3,000 miles away, so you can see for yourself that I am beginning to travel eastward, though in rather a roundabout fashion. One of the reasons which induced me to accept the very kind and flattering call of the congregation, in Portland was the hope, as occasioned by my experience in the West, that I may be enabled to be of great service to our case in the western part of our land. I really and truly believe that I be shall able to win many men for the movement, and also to gain much material help for the cause in the West. 83

If the move to Portland appeared as an odd choice to promote the cause of Zionism, Wise did find a conducive audience supportive of the idea of establishing a Jewish State, wherever it might happen. The historian Ellen Eisenberg has argued that German and eastern European Jews "felt tremendous affinity to the Zionist project," and Wise's arrival in the city only served to channel their enthusiasm by creating groups such as the Portland Zionist

83 Stephen Samuel Wise and Carl Hermann Voss, Stephen S. Wise: Servant of the People, [1st ed. (Philadelphia, Jewish Publication Society of America, 1969), 13. 
Society, making Portland an important center of zionist support in the Pacific Northwest. ${ }^{84}$

Significantly, Beth Israel welcomed the arrival of Wise with great expectations. The new rabbi clearly expressed his intention to independently control the pulpit far beyond the degree normally exercised by such a leader. To his fiancée, Louise, Wise wrote in September of 1900, "When I declared with emphasis, "this pulpit must be free, the congregation almost rose to its feet - I could feel it... After again asking the people to be my good angels and help me bear my burden, I added, our acts our angels are - I ask your lives, your works, your conduct, your character."85

In truth, Wise ran countercurrent to the general censorship that plagued many congregations and churches alike at the turn of the century. Indeed, Urofsky explained that the prevalent relation between ministers and boards of trustees often limited the ability of the former to exploit the pulpit in a free manner:

At other Jewish and non-Jewish congregations...many ministers were compelled either to formally or informally to clear their sermon topics with the boards of trustees. The rabbi or pastor may have been allowed a free hand in all matters of rituals or

\footnotetext{
84 Ellen Eisenberg, "Beyond San Francisco: The Failure of Anti-Zionism in Portland, Oregon," American Jewish History 86, no. 3 (1998): 72.

85 Wise, The Personal Letters of Stephen Wise, 72.
} 
religious interpretations, but especially in those churches or synagogues with a large wealthy clientele, comments on social issues were neither encouraged nor welcome. ${ }^{86}$

Accordingly, Wise's reluctance to sign a formal contract with the congregation hinted that the Board of Trustees of Beth Israel and the rabbi looked for a different relationship with the congregation. While Wise had felt constraints at B'nai Jeshurun, wherein most of his sermons had been eviscerated from their often-controversial social and political issues, Beth Israel reassured Wise that their pulpit would be his. Wise recalled in his autobiography that "My first and last words alike in my Portland congregation were the demand that its pulpit must remain free."87 In other words, Wise recognized communal constraints on the rabbinical office as unbearable and indicated that he would use his pulpit to advance current social issues such as child labor, gambling, and prostitution in a manner that would make the congregation aware of how the Ethical teachings as stated by Felix Adler were related to economic problems of everyday life.

\footnotetext{
86 Urofsky, A Voice That Spoke for Justice : The Life and Times of Stephen S. Wise, 36. 87 Stephen Samuel Wise, Challenging Years; the Autobiography of Stephen Wise (New York, Putnam's Sons, 1949), 44 .
} 
An examination of Wise's sermons suggests that his public discourse, other than that dealing exclusively with the religious duties of a reform rabbi, involved the right of ministers to discuss contemporary political issues, his defense of interfaith work, and his views on traditional Judaism. Similarly, the language of the sermon could be used for international matters. For example, when the Jewish position became more and more unbearable under the Czar in 1903 as Russian mobs ran amok and massacred Jews in the city of Kishineff, the news of this atrocity reached the outside world slowly; when it came, the Jews of Western Europe cried out in horror, held meetings, drew up protests, and framed petitions, asking the Russian government to punish the criminals. The news took even longer to reach the shores of the United States. In proof of his commitment to aid the Jews of Central Europe, Wise's lamentation on the calamitous situation suffered by thousands of Jews in the Pale led to an entire sermon given on October 1905 to repudiate the Russian absolutism system and the agony suffered by one of its most important minorities:

What Russia was she will continue to be as long as she remains under the blight of ducal tyranny and corruption and inhumanity, as long as imperial Russia exists. It is unspeakable tragic to hear the whisper 


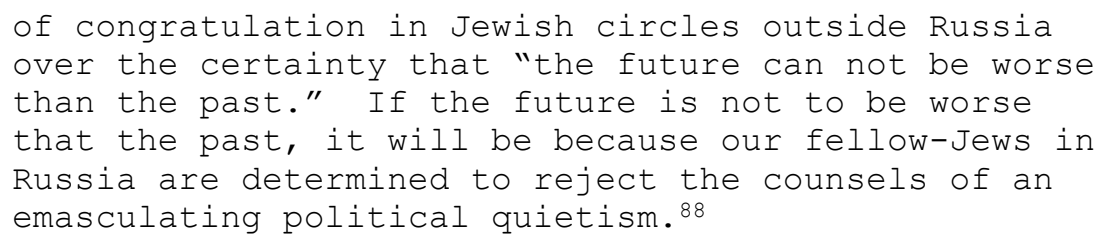

Put simply, Wise was calling for the creation of a national home for the Jews still living in Europe, thus reflecting a new phenomenon in Jewish life and in Jewish preaching.

In summation, the making of Rabbi Stephen Wise followed the trajectory of many other outspoken American rabbis as the nineteenth century drew to a close and a new century dawned. In so doing, the Americanization of Judaism was not merely a question of asserting the right to have prayers in vernacular or to shorten the worship, they were in fact the outer evidence of a living doctrine liberated from a system of a rigid set of laws for usefulness in modern life. Like his grandfather, Reb Joseph Hirsch Weisz, Wise boasted close relationships with Christians and was quickly absorbed into local governing councils and municipal agencies. Like his father, Rabbi Aaron Wise, his Judaism was more in tune with American standards and idioms put forth toward the end of the century, thus replacing religious practices with an

\footnotetext{
88 Stephen S. Wise, "A Glance at Jewish History in the Making," in Beth Israel Pulpit, ed. Congregation Beth Israel (Portland Or.) (Portland, Or 1905), 103.
} 
interest in social justice and social progress. Wise

combined these attributes upon his arrival to Portland to culminate in his path as a progressive reformer taking on the social and moral issues of the time. 


\title{
CHAPTER 3
}

THE STRUGGLE FOR SOCIAL JUSTICE

\begin{abstract}
I like this country [Portland] and its people. They are honest, genuine and not incapable of enthusiasm. Tell it not in Gath, or anywhere else, but it is just possible that I may decide within a year to take up my work here. I am wanted - I think. I can try to do good, earnest work here which I know remains to be done-Stephen Wise to Louise Waterman, 1899.89
\end{abstract}

Once in Portland, Rabbi Stephen Wise used sermons, speeches, interviews, and articles to mold a Jewish communal instinct that tied current social and economic issues to biblical texts and teachings. Because Portland in the early years of the twentieth century embodied what Wise called the lawless character of a frontier town, he carefully devoted countless hours to communal services. From child labor, gambling, prostitution, and the relief of necessitous people to municipal reform, Wise used his pulpit as a facilitator to encourage Jews and non-Jews to look beyond their own congregational needs to embrace the community at large. Shortly after their marriage in the fall of 1900, Wise declared to Louise, "We shall go out and seek the poor and go to them - happy as I am, I would rather be dead than inactive and useless."90 Wise's

89 Wise, The Personal Letters of Stephen Wise, 19. 90 Ibid., 60 . 
charismatic personality, imposing figure, and booming voice, armed with exceptional oratory skills accounted for some of his ability to transcend both groups, making him a different type of leader of American Jewry. In a time when oratory was a popular form of entertainment, Wise occupied a prominent position as an American public figure long before taking leadership of the Jewish community of Portland, and was able to manipulate this important medium to his advantage.

Since the United States never mandated a legal framework for child labor until 1916 when Congress passed the first federal legislation (invalidated by the U.S. Supreme Court two years later) to prevent interstate commerce in good produced by in factories and mines, the opportunity to learn a "craft" and industrial discipline provided an occasion for youth to be exploited and, possibly, be endangered. In the Pacific Northwest, children as young as five years old worked as cartoners while other youngsters served as cutters or fish cleaners for canneries along the Columbia River. Shucking oysters or picking shrimp for canning factories were often mentally debilitating and physically wearing, especially for young children. Child workers were often viewed as an 
alternative source of low-wage labor vying with their parents and other adults for employment, even at the cost of their health and education. ${ }^{91}$

Social reformers across the country heard horrible stories of children, boys and girls working endless shifts, dashed with water to keep them awake during the night, or girls spending more than sixteen hours a day in fish canneries in a never-ending race with tireless machines. ${ }^{92}$ As rumors and reports flew thick and fast about children at a young age working twelve hours a day in factories, the issue of child labor came under heavy scrutiny by groups such as Florence Kelley's National Consumers League. Wise's views were adamant on the subject of labor rights. He strongly supported child labor legislation and the improvement of working conditions. Yet because labor unions were embedded with conservative leaders that undercut their ability to efficiently organize, bargains most often could do little to alleviate the long hours and wretched conditions under which hundreds of thousands of children toiled at the turn of the century.

\footnotetext{
91 Edit Abbott, "A Study of the Early History of Child Labor in America," The American Journal of Sociology 14, no. 1 (1908): 15.

92 Urofsky, A Voice that Spoke for Justice : The Life and Times of Stephen S. Wise, 42.
} 
Wise's reaction took the form of joining the state Child Labor Commission, an official state agency that sought to make comprehensive legislation to secure more stringent measures to limit child labor. "The child labor question is to be put into my hands," he wrote his wife Louise in 1902, "and I will have it passed."93 In this manner, the commission's three major areas of responsibility were inspecting factories, enforcing new laws regulating child labor, and overseeing the number of hours women could work. Although Wise's intent was never to introduce a radical bill which he believed was politically unfeasible, he instead sought "to get some restrictive legislation on the books," as explained by Urofsky, "which could then be expanded and strengthened rather than propose an ideal bill, only to see it inevitably defeated."94 Wise's impact on the Commission is difficult to determine, for he resigned one year later, to be replaced by Julius L. Meier of the Meier and Frank Company. The decision to depart from the Commission is unclear but perhaps Wise sensed that he was extending himself too much. Completing his doctorate, serving

93 Wise, The Personal Letters of Stephen Wise, 84. 94 Urofsky, A Voice That Spoke for Justice : The Life and Times of Stephen S. Wise, 42. 
outlying Jewish communities, establishing relations with Christian groups, and organizing activities in the congregation all took an inevitable toll. In september 1903, as reported by Urofsky, Wise suffered from a complete physical breakdown and spent most of the next six months in Atlantic City to recover. While there, he wrote to Louise, "I know you will be glad to hear that I felt very well today after the best night's rest I have enjoyed in a month," he reported,"I feel persuaded that six weeks or two months of rest are going to restore me to strength."95 More troublesome was the continuing presence of gambling and prostitution that plagued Portland at the turn of the century. Portland was home to a well-known local operator, Walter F. "Jack" Matthews, who ruled the city by bringing together a coalition of business, gambling, prostitution, and liquor interests under his authority, which often stretched its tentacles into the corridors of City Hall. Under the auspices of the city's twenty-ninth mayor, George P. Frank, described "as a man of few principles and extreme rascality" in the words of historian E. Kimbark MacColl, Matthews secured a clerk position in the Board of Police Commissioners, which often served as a 
springboard to future political power.96 When Frank reneged on a campaign promise to divorce the police department from politics, gambling and prostitution flourished in unprecedented ways in the 1890s. One clear example was the thriving business of Madame Fanshaw across from the Portland Hotel in the Southwest district. Often referred by locals as the "Mansion of Sin," the brothel contained scores of prostitutes who were often picked up but usually released due to the lack of "absolute" proof.97 MacColl even reported that the Oregonian "refused to publicize the efforts of the local citizenry to clean up the town" because the persons most concerned in the maintenance of these abuses were the principal men of the city on whose patronage the paper relied. ${ }^{98}$ As explained by Jewel Lansing regarding the official tolerance for the vice trade witnessed by Laurence Pratt in 1902:

The "Red Light District" that stretched thirteen blocks along fourth street from Everett to Salmon, virtually on the doorstep of the county courthouse and only two blocks from city hall... He [Pratt] noted that an open vice policy must have existed under Mayor Rowe [1900-1902] for them to be so firmly ensconced, and that acceptance of such open cribs

\footnotetext{
96 E. Kimbark MacColl, The Shaping of a City : Business and Politics in Portland, Oregon, 1885-1915 (Portland, Or.: Georgian Press Co., 1976), 194.

97 Ibid., 199. 98 Ibid., 196.
} 
must have been supported by "influential business

interest." 99

To be sure, local businesses supported the trade

because they benefited from the rents and profits they

brought. Even the election of mayor William S. Mason in

1898 failed to dent the vice industry. Although Mason's

mandate was short because of his unexpected death a year

later, he initiated programs to clean up the brothels and

close the gambling establishments, including the Chinese

games and lotteries. His first political move was to

replace the entire police department in an attempt to break

up an espionage system that had been created under Matthews

and others which effectively thwarted vice arrests by the

regular patrolmen dispatched on raids from headquarters. ${ }^{100}$

Wise even witnessed an attempt to legalize gambling and

houses of prostitution in the City Council, prompting the

following note to Louise:

\begin{abstract}
Did I tell you that a desperate attempt was recently made by the "Sporting Element" to have Portland declared "wide open". The City Council were about to pass a resolution in favor of licensed vice, including houses of prostitution. Williams was wobbling, but Will Ladd stood like a rock. If the Police Commissioner had sanctioned the old method... I would have gone before the Grand Jury in the matter
\end{abstract}

99 Laurence Pratt, I Remember Portland, 1899-1915, A Vivid Look at Sturdy Days, 24, as quoted in Lansing, Portland : People, Politics, and Power, 1851-2001, 244.

100 MacColl, The Shaping of a City : Business and Politics in Portland, Oregon, $1885-1915,213$. 


\author{
at once. For the present "open gambling" has \\ received its quietus. ${ }^{101}$ \\ Wise's devotion to eradicate gambling and organized \\ prostitution translated into a series of dramatic and \\ colorful public speeches, stiff interviews, and sermons. \\ In one sermon, "Shall the City Be Wide Open?" he revealed \\ the plan of several city commissioners to license open \\ gambling and prostitution. In the aftermath of the \\ presentation, he wrote Louise: \\ Will you think me terribly vain if I say that you \\ would not have been ashamed of my address? "Shall the \\ City Be Wide Open?". There were moments in the \\ address when my hearers almost rose to me, thus when \\ I referred to the horrors of a city sharing the \\ profits of gambling and said, "This cannot be, this \\ must not be"; when I said, "There always will be \\ scarlet women, that is just as long as there are \\ scarlet men"; and, "Not to safeguard ourselves is to \\ be overwhelmed". I simply feel this now...I would have \\ felt like a coward running away. I have spoken my \\ mind. ${ }^{102}$ \\ Certainly, Wise was not the first public figure to \\ bemoan the rights of laborers, minorities, and municipal \\ reform. William S. U'Ren, a leading Progressive, \\ previously had voiced concerns about the undemocratic \\ nature of the Oregon political system and called for \\ drastic electoral reform including voters' initiatives, \\ legislature referenda, and direct primaries. U'Ren was
}

101 Wise, The Personal Letters of Stephen Wise, 88.

102 Ibid., 95-96. 
part of the fervent social reform movement sweeping through the United States from 1890 to 1920. Reformers had grown increasingly alarmed by the essential ways industrialization was endangering the social order of the nation and by its dire effects on working class men and women. The activists understood that all workers needed not only protective labor legislation but also a more active participation in state political development. Portland benefited from such ferment when the state legislature granted the city a "home rule" charter in 1903.103

Wise's participation in the effort to thwart child labor abuses, gambling, and organized prostitution was not without consequences for his pulpit and personal safety. Some members of his congregation directly or indirectly shared an interest in fish canneries or even in some cases, in gambling and prostitution. For instance, Sig Sidell, who ran a retail store in downtown Portland, was reported to be favorable to allowing slot machines in his store. The infuriated wise lashed out at him when visiting his store and reiterated the outrage of opening his business to vice. By the same token, rumors of physical threats

103 Lansing, Portland : People, Politics, and Power, 1851-2001, 250. 
against Wise spread quickly in downtown Portland. Not long after his altercation with Sidell, the rabbi overheard voices in a Turkish bath threatening his life, one of which vowed that "If I ever get near that son of a bitch, I'll shoot holes through him," as reported by Urofsky. ${ }^{104}$ It turned out to be an empty threat; but the Board of Trustees, of which Solomon Hirsch was President, questioned Wise's overt position on many issues relating to the economic well-being of the Congregation's members. Board member Charles Kohn even put forth the possibility that some congregants could leave the Temple or stop paying their memberships. Wise reported such concerns to his wife in 1902:

\footnotetext{
Yesterday Charles Kohn telephoned, ostensibly to inquire about my health. After a moment, he said that he had heard of the subject of my sermon today. "Business is terrible, why must you always be the leader?" If things go on this way, the members of the Temple won't be able to pay their dues: etc. And this from my best friend! Observe the veiled threat, the intimidation. I will give him my answer tonight - "I'll be damned sooner than be silent". ${ }^{105}$
}

Undeterred by potential threats or turmoil within the congregation, Wise continued to advance his social agenda with wit and determination. Adhering to a rigorous selfimposed regimen of no more than six hours of sleep a day, 
he explained his sleeping habits this way: "I concentrate in the matter of sleeping by night as I do in the mater of work during the day. I sleep more in an hour than most people can. That is why during a lifetime I have been able to get along with only five or six hours of sleep daily."106 In addition to his work on gambling and prostitution, Wise continued to drive himself to aid minority groups. Like the Jewish immigration to the Pacific Northwest, one of the main factors that attracted Chinese to the West was the Gold Rush, first discovered in California in 1848, then in Oregon in 1852. Very quickly the United States came to be known as Gim-San or Gold Mountain for allowing Chinese adventurers to become rich in a few years, ensuring prosperity for themselves and their families at home. The construction of the transcontinental Railroad from 1862 to 1869 and the salmon industry, unpopular with white laborers, increased the need for Chinese labor.107 The unfortunate effect of the growing visibility of Chinese was to draw increasingly fierce criticism and concern in the Portland area. With the expulsion of Chinese from Seattle

106 Jacob S. Minkin, "Stephen Wise's Autobiography," Congress Weekly 16 (1949): 10-12. 107 E. Kimbark MacColl and Harry H. Stein, Merchants, Money, and Power : The Portland Establishment, 1843-1913 ([Portland, Ore.]: Georgian Press, 1988), 238. 
and Tacoma in the 1880s, the city's Chinese community dramatically grew in numbers, settling for the most part between Ash on the north, Salmon on the South, Third on the West, and the Willamette on the east.

Increasingly, Portlanders saw the Chinese community as labor competition, a drain on the economy, and a moral threat represented by their brothels, opium dens, and alien tradition and beliefs. By the 1890s, widespread antiChinese prejudice was fanned into violence in Portland, culminating with the creation of an anti-Coolie club with the avowed purpose of stirring up emotions against the Chinese and "inventing" them to leave Portland.108 In the context of mounting discrimination toward Portland's Chinese and the introduction in 1902 of a bill by Oregon Senator John H. Mitchell to prohibit the Chinese from entering the United States and to regulate the terms of their residence, nativist spokesmen like Daniel Cronin pushed for expulsion. Such examples of discrimination engaged Wise to vehemently denounce the Chinese Exclusion Acts. As he recalled in his memoir:

It was not an honest measure. Nominally designed to keep Chinese immigration at a minimum, in practice it was to deal with every Chinese as if he were a coolie or a criminal. The law was to be one of many sops to

108 Lansing, Portland : People, Politics, and Power, 1851-2001, 186. 
be thrown to the Cerberus of anti-Chinese and antiJapanese prejudice. I spoke in earnest protest against it in my pulpit, doing this because I felt it my duty to take into the pulpit for consideration every problem of public life that involved a moral question. 109

By the 1890s, nativist sentiment targeted Roman Catholics and Jews as well as the Chinese. The period's economic depression intensified fears of lost wages and productivity and increased rates of unemployment, adding to anxiety of remaining jobs being taken by foreigners. With the help of the American Protective Association, which railed against the malign influence of foreigners and Roman Catholics, successive Portland mayoral candidates singled out minorities to bolster popular support. In his study of Oregon nativism, the historian Malcolm Clark described the basis of exclusionary beliefs:

Blacks because of their color, their alleged inferior
intellectual capacity and their equally sexual
superiority; Indians because they had the temerity to
resist the rape of their lands; Orientals because of
their skin, their eyes, their customs, their gods;
Jews because of their racial and religious
exclusiveness; Catholics because they owe allegiance
to the Pope of Rome. To a complete bigot, any of
these, or all of them, are permanently in the land.110

To be sure, by the late nineteenth century, the

decline of individual and community autonomy and the

109 Wise, Challenging Years; the Autobiography of Stephen Wise, 54.

110 Malcolm Clark, "The Bigot Disclosed: 90 Years of Nativism," Oregon Historical Quarterly 75 (1974). 
increasing regimentation and mechanization of society provoked concern, causing clergy, public officials, businessmen, and others to ponder whether industrial progress could be achieved without damaging the nation's physical and moral integrity. Accordingly, minority groups were often singled out for allegedly taking jobs from native-born Americans, thus contributing to the overall economic malaise. Chinese, Jews, Germans, and even Scandinavians shared a common pattern of overt discrimination based upon their language, accent, and look.111

Wise's opposition to Chinese exclusion aroused heated debate in the non-Jewish community, which occasionally led to racial slurs against the Jewish people. The Portland Oregonian seemed to have played an ambiguous role in Wise's struggle to help the local Chinese community. On many occasions, often, on its front page, the Oregonian welcomed Wise's efforts to denunciate the pending bill while at the same time allowing expression of dissenting from his opinion. For instance, on March 20th 1902, the newspaper

111 Roger Daniels, Coming to America : A History of Immigration and Ethnicity in American Life, 1st ed. (New York, NY: HarperCollins, 1990), 265-84. 
published a letter from a Portlander, who fundamentally

disagreed with Wise:

In your reprint of Rabbi Wise's pro-Chinese speech he
is made to say "We are willing to christianize them
but not Americanize." Who does the learned rabbi
include in that "we"? He will hardly be willing to
include himself...would not America have been millions
of money and a good many lives "to the good" if the
missionaries had stayed home and the American
contingent concentrated their efforts on the
conversion of the learned rabi and his synagogue
from the error of their ways.112
Wise"s reaction to the Oregonian was confounded and

bemused. He wrote to Louise that "you can compare what I

said with that stuff the Oregonian attributes to me...the

newspaper reports are misleading and ridiculous. I wish

they would not even refer to my addresses sooner than do

things that way." Weeks later, the Oregonian published an

article that praised his work on behalf of the Chinese

community while at the same time slurring the Jewish

people:

Dr. Wise is entitled to a great deal of credit for

his championship of the chinese, though it proceeds upon mistaken grounds and insufficient information. He belongs to a race which has known persecution, but which is generally most ungenerous toward other creeds and races. It is a rare thing to find a Jew who does not hate a Catholic... It is remarkable and creditable therefore, that Dr. Wise rise above race prejudice to speak a good word for the Chinaman. ${ }^{113}$

\footnotetext{
112 As quoted in Shapiro, "A Reform Rabbi in the Progressive Era: The Early Career of Stephen S. Wise", 98 .

113 Ibid., 99.
} 
Similarly, William U'Ren, whose devotion to reforming the political system won him widespread loyalty, declined to endorse Wise in his struggle to alleviate the lot of Portland's Chinese. On the contrary, U'Ren approached the issue of Chinese immigration in populist terms, stating in the Oregonian that same year that he could not oppose the pending bill because the majority of Oregonians agreed with its substance. "In the United States," he wrote in the newspaper in 1902, "men are elected to public office to enact the will of the people into law."114

Despite his criticism of newspaper coverage, Wise continually sought to preserve amity and better understanding between Jews and Christians. Encouraging Jewish-Christian cooperation on matters of philanthropy and social reform were of great importance throughout his career. In this manner, Wise corresponded with a range of Gentile acquaintances who often influenced his work and on whom he relied for particular outreach in their own communities: one of them was Portland's Reverend Thomas J. Eliot.

Following a dispute in the Protestant community, in which the Unitarian faith reportedly had been belittled by 114 Ibid., 97. 
the former, a benevolent society, the Ladies' Sewing Society, run by seven women, took the challenge to organize the first Unitarian church in the Portland area. By 1867, the activists were successful in gathering the needed funds to purchase a location and to provide a decent salary for Eliot to serve as minister. Born in st Louis, in 1841, Thomas was the first son of an evangelical minister. Educated both at Washington University and Harvard Divinity School, Thomas cultivated early on a commitment for the poor by learning their problems and investing time in working in the large sunday school in his father's church. Thus, Eliot lived out the spiritual ideals of the "Puritan tradition at best," as the historian Earl Morse Wilbur recounted," softened with time and shorn of narrowness and intolerance, but regarding the effort to cultivate irreproachable and unselfish character as one of the most important objects in life.115

In this manner, nurtured in such a home and "having been trained like a spartan to bear pain without complaint," Eliot's arrival in Portland in 1867 was for him a welcome departure from st Louis. Although Portland was

115 Earl Morse Wilbur, Thomas Lamb Eliot, 1841-1936 (Portland, Or., : Priv. print [by G. M. Allen and son], 1937), 9, 24-25. 
still plagued with poor communications with the outside world, primitive municipal governments, few church bodies, and a population that amounted to a mere seven thousand souls; this raw frontier town provided Eliot the opportunity to devote himself, unselfishly and unremittingly, in the words of his autobiographer, "to arousing, developing, and organizing the higher ideals of this community."116

With the church now well established, and the softening of the unfriendliness of the older congregations in the city, Reverend Eliot assumed the challenge of unfolding a provocative and unprecedented social program. Broadening his duty as a minister from the domain of the Kingdom of G-d to social activism, Eliot was the first to actively and aggressively address the many ills that afflicted the city, thus preceding Stephen Wise. From child welfare issues in regard to forsaken and neglected children to the proliferation and use of intoxicants or the traffic in them across Portland to the suffering of coalminers on the East coast to the relief of those suffering from the Franco-Prussian War, there was no small social problem or international crisis that did not require his 116 Ibid., 22. 
earnest attention. Assuming the leading part in many social reforms, Eliot was also the original proponent or inspirer of the fight against the disgraceful conditions existing in the county jail.117

Eliot's contributions to social reform were executed through what was considered to be one of the most powerful platforms for a minister at the time, the pulpit and public addresses. His constant communications to the newspapers also tackled the matter of corruption in politics, encouraging the duty of good citizens to look after their neighbors. Like Rabbi Stephen Wise, Eliot recognized that a forceful way of striking at the root of social evils in the spheres of child welfare, political corruption, and women's suffrage was to reach other congregations within the Christian community and other religious denominations. Reverend Eliot's struggle for prison reform, for instance, had not only called the attention of the public to the disgraceful condition of the county jail through sermons, public addresses, and meetings at city hall, but also demanded the creation of appropriate local and national agencies. In this manner, Eliot found in Rabbi Stephen Wise the ideal ally to alleviate the lot of children swept into 
jail for no other reasons than a lack of relevant public agencies or better options to deal with young delinquents.

Eliot had established the City Board of Charities in 1888 as the first step to suggest improvements and to remedy abuses in the county jail. Although the organization was rather dormant for the next decades for lack of funds or support from city hall, Rabbi Wise brought new urgency to the problem as part of his focus on child labor. Such publicity forced local government to take measures to encourage and improve the dire conditions in the county jail and implement alternative strategies for juvenile delinquency. The collaboration between the two ministers was so effective that by 1903, a volunteer agency, the Oregon Conference of Charities and Correction was established. The Committee in which Wise served as First Vice-President initiated public debate on issues such as juvenile courts, parole, and indeterminate sentences. ${ }^{118}$ With Reverend Eliot as President from 1902 to 1912, and Wise, and others assisting the panel helped to create the Oregon Prisoners' Aid Society. ${ }^{119}$

\footnotetext{
118 Nodel, The Ties between; a Century of Judaism on America's Last Frontier; the Human Story of Congregation Beth Israel, Portland, Oregon, the Oldest Jewish Congregation in the Pacific Northwest, 94.

119 Wilbur, Thomas Lamb Eliot, 1841-1936, 70-71.
} 
In retrospect, the collaboration between Eliot and Wise was in many respects beneficial not only for enacting a child labor legal framework and for reforming practices in the county jail, but for what they learned from each other. Wise found out that preaching was not always the only way to reach out to people. Instead, by using a combination of media, public addresses, and interviews granted to local and national newspapers, a practice at which Reverend Eliot had excelled, Wise considerably boasted the potency of his social and moral message. In turn, Eliot found in Rabbi Wise the ideal ground to bridge the theological gap between the two faiths, Wise had previously noted, "how readily disposed are a number of Jewish teachers, including myself, ... to recognize the place of Jesus in Jewish life - if not of Christ in our theology."120 In other words, interfaith work permitted Wise to undertake new ventures for building bridges between the Jewish and Christian worlds and, in particular, for enhancing the respectability of Jews and Judaism in the larger society.

Both Eliot and Wise, indeed, were moved by the forces of the modern secular age that underscored the relevance of 120 Wise, The Personal Letters of Stephen Wise, 32. 
their respective interpretations of Judaism and

Christianity. In this manner, Wise supported the idea of pulpit exchanges with Christian ministers, which resulted in varied lines of religious communication and social interaction. The experience in Portland was so genuine that Wise took the opportunity again to characterize the national core of Christianity as Jewish and predict the universalization of Judaism. Wise recalled in a personal letter in 1901:
Last night the Opera House was crowded, nearly a thousand people, the ministers on the stage, the introduction being by Dr. Bell. I spoke for one hour and I "arrived". The audience consisting 90\% of Christians, gave me undivided attention. I told them of Israel chosen for service, of Israel's emphasis upon conduct and morality flowering in personal purity and family holiness, of Jewish insistence upon social justice and righteousness, of Israel's dogmalessness witnessed by the vague teaching respecting the future life and the very certain injunctions touching this life, finally of Israel's plea and age-old stand for toleration and universal fellowship. I received a most flattering ovation at the close and vote of thanks.121
One can discern the unfolding process of Wise's realization from the sheering crowd, yet he was ever conscious of deep and immutable religious barriers. Even in the United States, they were confronted by vestiges of Christianity that were legally recognized and by pervasive social discrimination. Aware that the long history of the 
Jews and Christians had moved in separate orbits that rarely intersected in which conversion to Christianity was often put to the fore as the inevitable course of action for unconditional Christian acceptance, Wise expected Christians to respect his faith. In this manner, he sharply criticized Christian excerpts that relegated Judaism as a religion of superstition and was not shy of voicing the belief on many occasions that the revelation at Sinai, witnessed by more than three million Jews, was the core of both religions and acknowledged as a fundamental historical event. In 1902, Wise became exacerbated by some local Christians and only joined the state conference of Religion with reluctance:

I considered the matter very carefully: the invitation might have come three months earlier; with only three weeks between the Day of Atonement and my departure for New York, I feel that I cannot prepare myself with sufficient thoroughness. The theme is too big - the "Ethical Teachings of Jesus and the Prophets". I confess that I do not like the manner in which the title is framed, - it is unhistorical and unfair. Why place Jesus prior to the Prophets who antedated him 500-800 years? The Prophets of Judah and Israel stand apart in my judgment and are not to be tacked on to Jesus semi-parenthetically. I shall attend the conference and participate in the discussion without being on the program. ${ }^{122}$

Though Wise was actively collaborating with fellow

Christian in many social programs, he never lost sight that he was first and foremost a Jew. If Christians and Jews 
found new ways to work together, the theological gap between the two faiths reminded them of their distinctiveness in their appeal and mission. While Wise understood the shortcomings of their collaboration, pragmatism often superseded his fear of Christian proselytization. At a time when anti-Semitism continued to fester in America and entertained the idea of dual loyalty as a threat to national cohesion, Wise determinedly sought Christian approval and respect and purposefully rejected a transcendent Judaism in favor of union with like-minded Christians.

Therefore, to Wise, the idea of a free pulpit was intimately connected with social justice and social progress to pave the way not only to social betterment, but more importantly, to re-connect with the Christian community at large. Working tirelessly in child labor, gambling and prostitution, sometimes at the expense of his personal safety or career, definitely projected Wise from local to national prominence, thus proving once and for all that rabbis were no longer limited by the confines of their congregation. Similarly, although relationships between Christians and Jews had been for too long based upon tenacious and fallacious quandaries over theology, often 
forcing American Jews to come to grips with an ambiguous situation, the partnerships between Wise and Eliot proved to be a huge source of help for minorities and young delinquents. 


\section{CONCLUSION}

By the time Rabbi Stephen Wise left Portland to New York in 1906 to become the spiritual leader of the newly formed Free Synagogue, Portland had experienced a remarkable transformation from an isolated settlement of a few hundred souls to a major economic and social hub in the Pacific Northwest. With a population that reached more than 200,000 at that time, the effects of industrialization, mass immigration, and increased mobility dramatically shaped the city in unprecedented ways. Yet the absence of clothing factories, large foundries, and modern construction led skilled labor to remain in the East. The net result for Portland, often described as an economic backwater, was to continue to offer many opportunities to craftsmen over workingmen in industry. Peddling at first was therefore the primary occupation for Jews which turned into retail stores as their integration and assimilation flourished in the Rose City.

Triggered by the discovery of gold in the mid nineteenth century in California, tens of thousands of immigrants from the eastern United States, Europe, and Asia rushed to the Pacific Coast. Among the newcomers were many 
thousands of Jews who eventually settled in many parts of the West, particularly in California and Oregon. Jews who ventured from the East and abroad to the shores of the Pacific Coast were predominantly merchants who recognized the possibilities in a growing urban center for profit in a new market and a new region. They first established small businesses which sold food, clothing, or even hardware in the mining areas later became department stores. In this way, the Jews of the West were largely an urban group in nature who held occupations that reflected the needs of developing urban centers such as San Francisco and Portland.

In stark contrast to the East Coast where an industrial economy developed at a fast pace and provided low-level industrial and craft opportunities to immigrants, Portland offered trade-oriented newcomers excellent opportunities. Because of its strategic location, nestled at the point where the Willamette and the Columbia Rivers converged, the city opened opportunities for mineral and agricultural produce. Added to the developing transportation network of steamboats and, later, railroads, trading opportunities enhanced the fortune and social visibility of Jewish merchants as never before. Yet as the 
majority of American Jews of German origin were becoming well assimilated, many thousands of poor, Yiddish-speaking Jews of Eastern Europe origin began to immigrate to the Pacific Northwest.

Perhaps because the integration of German Jews in the city was marked by considerable success, the arrival of Eastern European Jews did not generate enthusiasm or sympathy. The last quarter of the nineteenth century witnessed a significant rise in social discrimination in the United States that kept Jews out of private schools, clubs, and resorts. As nativism grew stronger, the influx of thousand of Russian Jews who reflected the tradition of the Shtetl in their garments and languages posed a threat to the successful yet fragile assimilation of their German brethren. Portland was not spared, and the establishment of lodges mirrored the fear and frustration of a community that determined to not simply adopt the models set out for them by their fellow Jews, but instead to preserve their identity intact and remain loyal to the teachings of their ancestors.

It was, therefore, in this context that stephen S. Wise made the decision to accept the Portland offer to officiate at Congregation Beth Israel in the fall of 1899. 
While it is true that Wise removed himself from the main center of Zionist activity in America and settled in a new environment populated by less that three hundred Jews, it was nonetheless here that he developed a "philosophy of Liberal Judaism that was coherent and went beyond mere haphazard changes in outward ritual. It became a program of positive action."123 Wise's early commitment to Ethical Judaism as evidenced at the B'nai Jeshurun congregation, was now refined in unprecedented ways in Portland. By replacing religious practices with social causes, by declaring that traditional Judaism had no place in America where Judaism could demonstrate flexibility and openness, and by breaking off the parochial shell of many congregations, Wise worked diligently to promote interfaith harmony and progressive causes that literally put Portland on the map. As eloquently expressed by Wise biographer, William M. Kramer, "Jewish speaking, Wise put Portland, Oregon on the map. Until his time, it was terra incognita."124

\footnotetext{
123 Nodel, The Ties between; a Century of Judaism on America's Last Frontier; the Human Story of Congregation Beth Israel, Portland, Oregon, the Oldest Jewish Congregation in the Pacific Northwest, 90 .

124 William M. Kramer, "Rabbi Stephen S. Wise, Prophet of Portland, Oregon," Western States Jewish History XXVII, no. 1 (1994): 274.
} 
To be sure, Wise's new religious theology involved a combination of family heritage and the influence of scholars and religious thinkers that helped him synthesize his belief in religious liberalism with a strong attachment to the Jewish people. From traditional Orthodox Judaism practiced by his grandfather to Conservative Judaism carried out by his father, stephen Wise gradually moved to a more liberal form of Judaism that showed an almost complete neglect of Talmudic sources and rabbinic Judaism. In doing so, Wise's main contribution to Reform Judaism was that social justice would be the core inspiration of his teachings and practices with the ultimate goal to raise the social conscience of all men and thereby universalize the meaning of the Jewish religion.

In a similar fashion, Stephen Wise's development of a liberal religious theology was similar to that of figures such as Richard Gottheil, Adolf Jellinek, Emil Hirsch, and Thomas Davidson. These thinkers helped Wise remain loyal to his Jewish heritage and re-emphasize the spiritual and ethical content of Judaism by minimizing the importance of outward observance and ceremony and magnifying the doing of justice. As befitting a child of the Progressive Era, Wise labored to reconcile his interpretation of Judaism to the 
realities of American life. Unlike the typical rabbi of mid-nineteenth-century America, for whom the synagogue and pulpit must steer clear of contemporary matters, Wise fought for and won the right for a free pulpit. In other words, the battle for social justice and radical causes became the focal point of his Judaism. And as he assumed that his own deep Jewish commitments and Jewishness in their social struggles would no longer reflect traditional Judaism, Liberal Judaism came to be. Ultimately, this thesis has attempted to describe Stephen Wise in Portland where he was able, with a freer hand, to implement a program that minimized ritual observances and emphasize social issues instead. By exploring his intellectual development one heavily influenced by his family heritage and scholars and religious thinkers alike, this work has sought to demonstrate that Wise's Jewish activism in social and political life was essential to his sense of Jewish commitment as well as his deep-seated Americanism. In this way, this thesis has sought to answer what did Reform Judaism meant to Wise and how and why he came to it. While his attitude to Judaism was novel because Wise actively sought to interpret American progressive liberalism in 
Jewish terms, this monograph has attempted to gauge how this reformist rabbi balanced his Jewish and American identification. In the end, Wise was no less concerned with the social ills that plagued America at the turn of the century that with his profound ethnic attachment.

As with any scholarly work, questions remain. Why did a man whose leadership style was characterized by public confrontation and agitation act with such restraint in the case of the anti-Chinese attitudes exposed in Portland in the 1900s? Was it the fear of fueling the rising tide of anti-Semitism in the United States that limited his actions or was Wise convinced that confrontational tactics would achieved nothing in this particular case? And how Wise's re-prioritization of the synagogue from liturgy to social activism helped to retain disaffected Jews who though not affiliated with Jewish organizations were reawakened to their Jewishness? Such questions suggest that the study of Stephen S. Wise retains relevance in enabling us to understand how the American Jewish community dealt with issues of ethnic identity in a time of social, economic and political transformation at the turn of twentieth century America . 


\section{BIBLIOGRAPHY}

Abbott, Carl. Portland : Gateway to the Northwest. Tarzana, Calif.: American Historical Press, 1997.

Abbott, Edit. "A Study of the Early History of Child Labor in America." The American Journal of Sociology 14, no. $1(1908): 15-37$.

Adler, Felix, and Leslie Willis sprague. The Religion of Duty. New York.: McClure, Phillips \& Co., 1905.

B'nai B'rith. District no. 4. Portland Lodge no. 65. Commemorating the First Hundred Years of the B'nai B'rith Lodge of Portland, Oregon, 1866-1966. [Portland, Or.,: Heims \& Turtledove., 1966. Bartlett, Roger P. A History of Russia, Palgrave Essential Histories. Houndmills, Basingstoke, Hampshire ; New York: Palgrave Macmillan, 2005.

Blackford, Mansel. "The Lost Dream: Businessmen and City Planning in Portland, Oregon: 1903-1914." The Western Historical Quarterly 15, no. 6 (1984): 39-56. Clark, Malcolm. "The Bigot Disclosed: 90 Years of Nativism." Oregon Historical Quarterly 75, (1974): $109-90$. 
Cohen, Naomi Wiener. What the Rabbis Said : The Public Discourse of Nineteenth-Century American Rabbis. New York: New York University Press, 2008.

Daniels, Roger. Coming to America : A History of Immigration and Ethnicity in American Life. 1st ed. New York, NY: HarperCollins, 1990.

Diner, Hasia R. The Jews of the United States, 1654 to 2000, Jewish Communities in the Modern World 4. Berkeley: University of California Press, 2004. Dinnerstein, Leonard. Antisemitism in America. New York: Oxford University Press, 1994. Eisenberg, Ellen. "Beyond San Francisco: The Failure of Anti-Zionism in Portland, Oregon." American Jewish History 86, no. 3 (1998): 309-21.

- "Transplanted to the Rose City: The Creation of East European Jewish Community in Portland, Oregon." Journal of American Ethnic History 89, (2001): 82-97.

Gay, Ruth. The Jews of Germany : A Historical Portrait. New Haven: Yale University Press, 1992.

Gillman, Neil. Conservative Judaism : The New Century. West Orange, N.J.: Behrman House, 1993. Gitelman, Zvi Y., and Yivo Institute for Jewish Research. A Century of Ambivalence : The Jews of Russia and the 
Soviet Union, 1881 to the Present. 2nd expanded ed. Bloomington: Indiana University Press, 2001.

Heschel, Abraham Joshua. The Prophets. [1st ed. New York, : Harper \& Row, 1962.

Higham, John. Strangers in the Land; Patterns of American Nativism, 1860-1925. New Brunswick, N.J.,: Rutgers University Press, 1955.

Jacob, Walter. "Prophetic Judaism: The History of a Term." Journal of Reform Judaism Spring, (1979): 33-46. Jewish frontier., and Jewish Frontier Association. Jewish Frontier Anthology, 1934-1944. New York, : Jewish frontier association, 1945.

Kaganoff, Nathan W. "The Traditional Jewish Sermon in the United States from Its Beginnings to the First World War." Doctoral Dissertation, American University, 1960.

Kramer, William M. "Rabbi Stephen S. Wise, Prophet of Portland, Oregon." Western States Jewish History XXVII, no. 1 (1994): 53-72.

Kriwaczek, Paul. Yiddish Civilisation : The Rise and Fall of a Forgotten Nation. London: Weidenfeld \& Nicolson, 2005 . 
Lansing, Jewel Beck. Portland : People, Politics, and Power, 1851-2001. Corvallis: Oregon State University Press, 2003 .

Léon, Abraham. The Jewish Question : A Marxist Interpretation. New York, : Pathfinder Press, 1970. Lowenstein, Steven. The Jews of Oregon, 1850-1950. 1st ed. Portland, Or.: Jewish Historical Society of Oregon, 1987 .

MacColl, E. Kimbark. The Shaping of a City : Business and Politics in Portland, Oregon, 1885-1915. Portland, Or.: Georgian Press Co., 1976.

MacColl, E. Kimbark, and Harry H. Stein. Merchants, Money, and Power: The Portland Establishment, 1843-1913. [Portland, Ore.]: Georgian Press, 1988.

May, Max Benjamin. Isaac Mayer Wise, the Founder of American Judaism : A Biography. New York: G.P. Putnam's Sons, 1916.

Merriam, Paul Gilman. "Portland, Oregon, 1840-1890: A Social and Economic History." Ph.D. diss., University of Oregon, 1971 .

Mervis, Leonard J. "The Social Justice Movement and the American Reform Rabbi." In Critical Studies in American Jewish History; Selected Articles from 
American Jewish Archives, edited by Jacob Rader Marcus and American Jewish Archives., 3 v. Cincinnati,: American Jewish Archives, 1971.

Minkin, Jacob S. "Stephen Wise's Autobiography." Congress Weekly 16, (1949): 10-12.

Neugroschel, Joachim. The Shtetl. New York: Richard Marek Publishers, 1979.

Nodel, Julius J. The Ties between; a Century of Judaism on America's Last Frontier; the Human Story of Congregation Beth Israel, Portland, Oregon, the Oldest Jewish Congregation in the Pacific Northwest. Portand, Or.,: Temple Beth Israel, 1959.

Reissner, H.G. "The German-American Jews (1800-1850)." The Leo Baeck institute Yearbook 10, (1965): 47-116. Riis, Jacob A. How the Other Half Lives; Studies among the Tenements of New York, American Century Series, S-12. New York, : Sagamore Press, 1957. Rischin, Moses, and John Livingston. Jews of the American West, American Jewish Civilization Series. Detroit: Wayne State University Press, 1991.

Rischin, Moses, and Multicultural History Society of Ontario. The Jews of North America. Detroit: Wayne State University Press, 1987. 
Sachar, Howard Morley. A History of the Jews in America. New York: Knopf, 1992.

Sarna, Jonathan D. American Judaism : A History. New Haven: Yale University Press, 2004.

Segel, B. W., and Richard S. Levy. A Lie and a Libel : The History of the Protocols of the Elders of Zion. Lincoln, NE: University of Nebraska Press, 1995. Shapiro, Robert Donald. "A Reform Rabbi in the Progressive Era: The Early Career of Stephen S. Wise." Ph.D. diss., Harvard University, 1984.

Shpall, Leo. "Jewish Agricultural Colonies in the Unites States." Agricultural History 24, no. 2 (1950): $120-46$

Slezkine, Yuri. The Jewish Century. Princeton: Princeton University Press, 2004 .

Sorin, Gerald. A Time for Building : The Third Migration, 1880-1920, The Jewish People in America. Baltimore: Johns Hopkins University Press, 1992.

Strauss, Raphael. "The Jews in the Economic Evolution of Central Europe." Jewish Social Studies 3, no. 1 $(1941): 15-40$. 
Toll, William. "Ethnicity and Stability: The Italians and Jews of South Portland, 1900-1940." Pacific Historical Review 54, no. 2 (1985): 161-89.

- "Fraternalism and Community Structure on the Urban Frontier: The Jews of Portland, Oregon: A Case Study." The Pacific Historical Review 47, no. 3 (1978): $369-403$

- The Making of an Ethnic Middle Class : Portland Jewry over Four Generations. Albany: State University of New York Press, 1982 .

Urofsky, Melvin I. A Voice That spoke for Justice : The Life and Times of Stephen S. Wise, Suny Series in Modern Jewish History. Albany: State University of New York Press, 1982 .

Wilbur, Earl Morse. Thomas Lamb Eliot, 1841-1936. Portland, Or., : Priv. print [by G. M. Allen and son], 1937. Wise, Stephen S. "A Glance at Jewish History in the Making." In Beth Israel Pulpit, edited by Congregation Beth Israel (Portland Or.). Portland, Or 1905. Wise, Stephen Samuel. Challenging Years; the Autobiography of Stephen Wise. New York, : Putnam's Sons, 1949.

- The Personal Letters of Stephen Wise. Boston, : Beacon Press, 1956 . 
Wise, Stephen Samuel, and Carl Hermann Voss. Stephen S. Wise: Servant of the People. [1st ed. Philadelphia, : Jewish Publication Society of America, 1969. 